\title{
Age and sex determination of Mallards Anas platyrhynchos in autumn
}

\author{
Ålders- och könsbestämning av gräsänder Anas platyrhynchos på hösten
}

\author{
STINA ANDERSSON, DANIEL BENGTSSON, MAGNUS HELLSTRÖM \& \\ JONAS WALDENSTRÖM
}

\begin{abstract}
Male and female mallards Anas platyrhynchos are easily told apart, whereas ageing is problematic, due to individual timing of moult and lack of easily defined age criteria. From examination and photographic documentation of mallards caught at Ottenby Bird Observatory $\left(56^{\circ} 12^{\prime} \mathrm{N}\right.$, $\left.16^{\circ} 24^{\prime} \mathrm{E}\right)$, we describe nine characters of plumage and bare parts to be used for ageing in autumn. The reliability of these characters was tested by letting experienced bird ringers determine putative age of birds from photos. Age determination from any single character proved to be uncertain, as correctly assigned mallard photos of each character was in the range of $51-85 \%$ for males and $48-89 \%$ for females. For both sexes, the lowest figure represented post-humerals and the highest represented

tertials. Rectrices, tertial coverts, and greater coverts had high scores (71-85\%). Using all characters, $91 \%$ of the males and $95 \%$ of the females were correctly aged. As young mallards, with the progress of pre-breeding moult (completed from October onwards), acquire tail and tertials identical to adults, untypical individuals are better not assigned to an age category.

Stina Andersson and Magnus Hellström, Ottenby Bird Observatory, Ottenby 401, SE-386 64 Degerhamn, Sweden Daniel Bengtsson and Jonas Waldenström, Centre for Ecology and Evolution in Microbial Model Systems (EEMiS), Linnaeus University, SE-39182 Kalmar, Sweden Corresponding author:jonas.waldenstrom@lnu.se
\end{abstract}

\section{Received 26 November 2015, Accepted 1 March 2016, Editor: D. Hasselquist}

\section{Background}

The mallard Anas platyrhynchos is the most numerous and widespread dabbling duck in the world with a Holarctic distribution covering most of the northern hemisphere, including Alaska and southern Greenland. It is only absent in desert areas, the extreme north, and tropical regions. The global population is estimated to number at least 19 million individuals, of which 7.5 million occur within Europe (Wetlands International 2006, 2015). Additionally, millions of mallards are released for hunting each year, primarily in the northern hemisphere (Champagnon et al. 2013). The mallard is an important model species for research on ecological processes (Gunnarsson et al. 2006), harvest management (Nichols et al. 2007), and disease (Wallensten et al. 2007). Correctly assigning birds to age and sex categories are pivotal for research purposes; for example, age can have strong effects on infection susceptibility (Costa et al. 2010, van Dijk et al. 2014) and population dynamics (Hauser et al. 2007). Sex determination based on plumage is simple, except for very young birds. Males display a conspicuous breeding plumage with green head and mainly grey body, while females have a mainly brown plumage speckled with black. Ageing, however, can be far more challenging, partly because of the protracted breeding season, where the difference between early and late clutches can differ with almost five months (Cramp \& Simmons 1977), and the individual temporal variation in performance of moult.

A key for age determination is to understand the process of moult (Ginn \& Melville 1983). The downy plumage of ducklings is during body growth replaced by juvenile feathers. At the age of 2-4 months, juvenile mallards perform a partial moult of some feathers on the head, neck, mantle, scapulars, breast, and flanks in late summer (mainly JulySeptember, correlated to hatching date) (Cramp \& Simmons 1977, Reeber 2015). Both young and adults undergo pre-breeding moult from AugustDecember, but the process may be prolonged during winter. This moult includes most body feathers, scapulars, tertial coverts, tertials, and tail, but very 
Table 1. Feather terms and abbreviations used in this article (see also Figures 1-2).

Fjäderterminologi och förkortningar som används i artikeln (se även Figur 1-2)

\begin{tabular}{|c|c|}
\hline $\begin{array}{l}\text { Abbreviation } \\
\text { Förkortning }\end{array}$ & $\begin{array}{l}\text { Explanation } \\
\text { Förklaring }\end{array}$ \\
\hline 1 cy & $\begin{array}{l}1^{\text {st }} \text { calendar-year, i.e. from hatching until January } 1^{\text {st }} \text {. } \\
\text { Första kalenderåret, } d v \text { s. från kläckning tom. } 31 \text { december. }\end{array}$ \\
\hline $2 \mathrm{cy}+$ & $\begin{array}{l}2^{\text {nd }} \text { calendar-year and higher, i.e. from January } 1^{\text {st }} \text { the year after hatching, which me- } \\
\text { ans that a bird is } 2 \text { cy+ from about six months age onwards. } \\
\text { Andra kalenderåret och senare, dvs. från } 1 \text { januari året efter kläckningen, vilket } \\
\text { innebär en fägel från ungefär sex månaders ålder och äldre. }\end{array}$ \\
\hline $\begin{array}{l}\text { Alula } \\
\text { Lillvinge }\end{array}$ & $\begin{array}{l}\text { The miniature outermost primary (the "thumb") and its coverts. } \\
\text { Förkrympta yttre handpennan ("tummen") och dess täckare. }\end{array}$ \\
\hline $\begin{array}{l}\text { Greater coverts }(\mathrm{GC}) \\
\text { Större täckare }\end{array}$ & $\begin{array}{l}\text { The first row of feathers covering the secondaries. Numbering starts from outer to } \\
\text { inner, as with secondaries. Mallards usually have } 12 \mathrm{GC} \text {, occasionally } 13 \text {. } \\
\text { Första raden av fjädrar som täcker armpennorna. Numreringen startar utifrån och går } \\
\text { inåt, liksom för armpennorna själva. Gräsanden har vanligen } 12 \mathrm{GC} \text {, i undantagsfall } 13 \text {. }\end{array}$ \\
\hline $\begin{array}{l}\text { Median coverts (MC) } \\
\text { Mellersta täckare }\end{array}$ & $\begin{array}{l}\text { The second row of feathers covering the secondaries. } \\
\text { Andra raden av fjädrar som täcker armpennorna. }\end{array}$ \\
\hline $\begin{array}{l}\text { Lesser coverts (LC) } \\
\text { Mindre täckare }\end{array}$ & $\begin{array}{l}\text { An area of coverts anterior of the median coverts. } \\
\text { Täckarna framför mellersta täckarna. }\end{array}$ \\
\hline $\begin{array}{l}\text { Post-humerals (PH) } \\
\text { Posthumeraler }\end{array}$ & $\begin{array}{l}\text { Feathers placed in between the tertials and the scapulars. } \\
\text { Fjädrar som sitter mellan tertialerna och skulderfjädrarna.. }\end{array}$ \\
\hline $\begin{array}{l}\text { Primaries (PP) } \\
\text { Handpennor }\end{array}$ & $\begin{array}{l}\text { The flight feathers of the hand. Mallards have ten PP, excluding the remicle which } \\
\text { is the stunted P11. Numbering starts from inner to outer, as with primary coverts. } \\
\text { Handens vingpennor. Gräsanden har tio PP, samt den rudimentära P11. Numrering- } \\
\text { en startar inifrän och går utät. }\end{array}$ \\
\hline $\begin{array}{l}\text { Primary coverts }(\mathrm{PC}) \\
\text { Handtäckare }\end{array}$ & $\begin{array}{l}\text { The feathers covering the primaries, often mainly referring to the greater primary co- } \\
\text { verts. Mallards have nine PC and numbering starts from inner to outer, as with primaries. } \\
\text { Fjädrarna som täcker handpennorna, ofta även kallade större handtäckarna. }\end{array}$ \\
\hline $\begin{array}{l}\text { Rectrices (RR) } \\
\text { Stjärtpennor }\end{array}$ & $\begin{array}{l}\text { The main feathers of the tail. Mallards have ten pairs and numbering starts from the } \\
\text { central pair (R1 to R10). In male breeding plumage, the central two pairs of RR are } \\
\text { small, black, and upcurled, almost blending in with uppertail coverts. } \\
\text { Stjärtens egentliga fjädrar. Gräsanden har tio par och numreringen startar från det } \\
\text { centrala paret (R1 till R10). Hos hanen i praktdräkt är de två centrala paren av RR } \\
\text { korta, svarta och uppåtsvängda, och blandar sig nästan med de övre stjärttäckarna. }\end{array}$ \\
\hline $\begin{array}{l}\text { Scapulars } \\
\text { Skulderfjädrar }\end{array}$ & $\begin{array}{l}\text { The shoulder feathers (between tertials/coverts and body/back). } \\
\text { Fjädrarna mellan tertialerna/täckarna och ryggen. }\end{array}$ \\
\hline $\begin{array}{l}\text { Secondaries (SS) } \\
\text { Armpennor }\end{array}$ & $\begin{array}{l}\text { The flight feathers of the arm, where the speculum and the white trailing edge is } \\
\text { located. Most mallards have } 10-11 \mathrm{SS} \text {, but some have } 12 \text { (excluding the tertials). } \\
\text { Numbering starts from outer to inner, as with greater coverts. } \\
\text { Armens vingpennor, där vingspegeln och den vita vingbakkanten sitter. De flesta } \\
\text { gräsänder har 10-11 SS, men somliga har 12. Numreringen startar utifrän och inåt, } \\
\text { samma som för större täckarna. }\end{array}$ \\
\hline $\begin{array}{l}\text { Tertial coverts }(\mathrm{TC}) \\
\text { Tertialtäckare }\end{array}$ & $\begin{array}{l}\text { The (greater) coverts covering the tertials. } \\
\text { De större täckare som täcker tertialerna. }\end{array}$ \\
\hline $\begin{array}{l}\text { Tertials (TT) } \\
\text { Tertialer }\end{array}$ & $\begin{array}{l}\text { The innermost flight feathers of the arm, which on a folded wing generally cover the } \\
\text { secondaries. Mallards have four TT and numbering starts from outer (T1) to inner } \\
\text { (T4), T2 being longest. } \\
\text { De innersta armpennorna, vilka i allmänhet täcker övriga armpennor när vingen är } \\
\text { ihopfälld. Gräsanden har fyra TT och de numreras frän den yttre (T1) till den inre } \\
\text { (T4), T2 är längst. }\end{array}$ \\
\hline
\end{tabular}




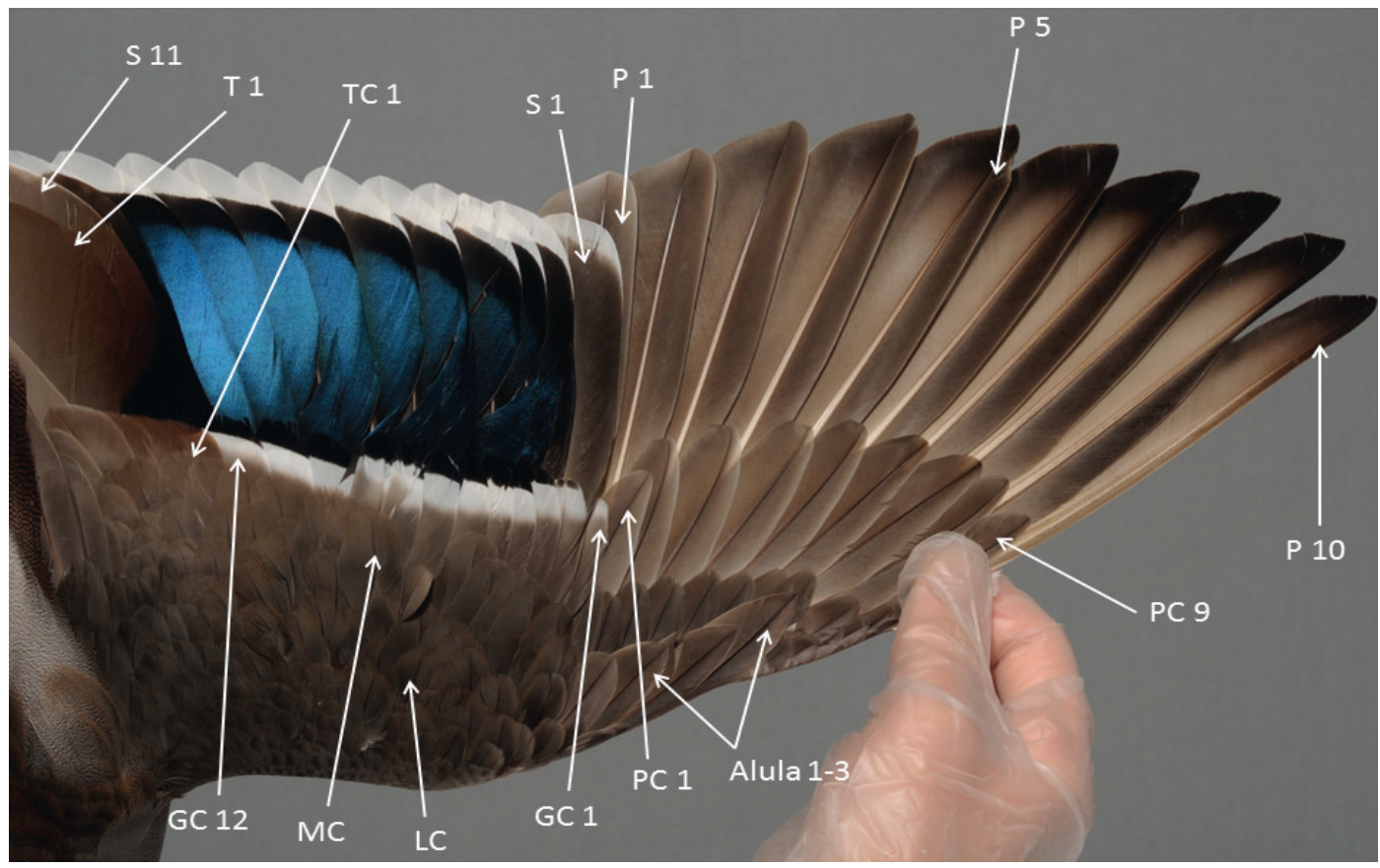

Figure 1. Mallard (male) wing showing location of greater coverts (GC), median coverts (MC), lesser coverts (LC), primary coverts (PC), alula, primaries (PP), secondaries (SS), tertial coverts (TC), and tertials (TT).

Vinge av hane med olika fjädergrupper markerade. Svenska termer i Tabell 1.

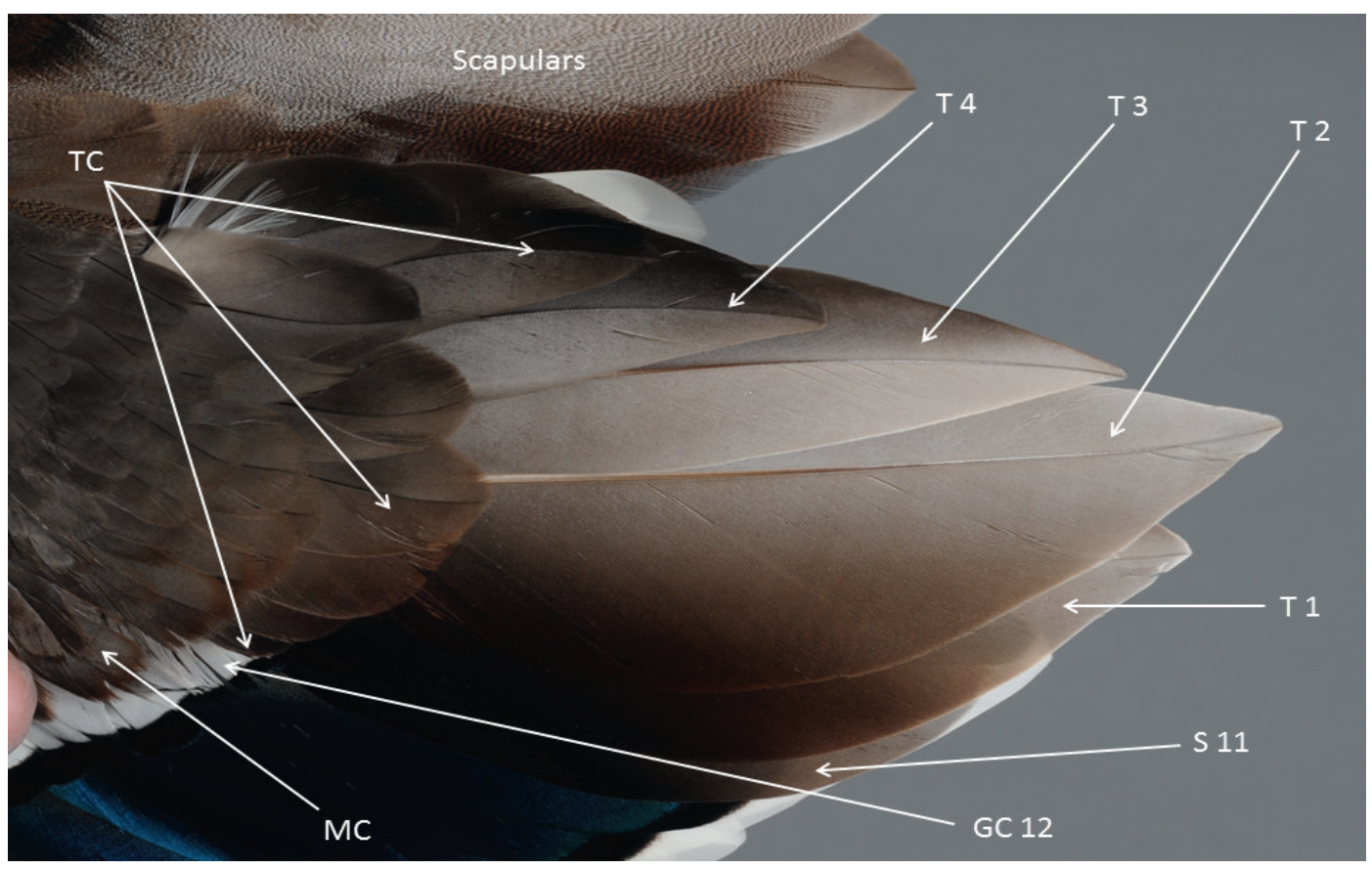

Figure 2. Mallard (male) wing showing location of scapulars, tertial coverts (TC), tertials (TT), median coverts (MC), greater coverts (GC), and secondaries (SS).

Vinge av hane med olika fjädergrupper markerade. Svenska termer $i$ Tabell 1. 
few lesser, middle, and greater coverts, and no primaries and secondaries (see Table 1 and Figures 1-2 for location of feather groups). The retained feather groups allow determination of juveniles until replaced during the next year. Young females also retain at least some juvenile tertials and tertial coverts, whereas most males have moulted all tertials by late November (Hopper \& Funk 1970). Males are thought to perform more extensive tertial moult due to sexual selection (Ashley et al. 2007), and perhaps is sexual selection also responsible for the "extra" moult of mainly head and neck feathers noted in males in February-March (Reeber 2015).

In January-May, females perform a moult (of similar extent as the preceeding one) to acquire an even more cryptic plumage during nesting, broodrearing, and moult of flight feathers, while males moult into a female-like eclipse plumage in MayJuly (Reeber 2015). Both sexes are flightless for about one month when all remiges (primaries and secondaries) are lost simultaneously during the summer (mainly late June-August), latest in successfully breeding females. It has been suggested that this "drastic" moult strategy is an adaption to the fact that for Anseriformes birds, due to the morphology of relatively small wing area and heavy body, even the loss of a few remiges would severely affect the ability to fly. Consequently, it might be better to become flightless for one month than to fly weakly for several months, as would be the duration for gradually replacing the remiges (Reeber 2015). Regardless of the strategy's background reason, moulting in aggregations decreases the risk of predation (Beauchamp 2004).

Compared to passerine birds (order Passeriformes), less literature is available for age and sex determination of non-passerines. The most widespread reference is the Identification guide to European non-passerines by Baker, published by British Trust for Ornithology (BTO) in 1993. However, there is also duck specific literature for Europe, including an analysis of wing characters by Boyd et al. (1975), and an identification manual for age and sex based on hunted ducks from the French hunting organization OFNS (Mouronval 2014). In North America, U.S. Fish and Wildlife
Service organizes a project in which hunters contribute detached wings in order to determine species, sex and age composition in the duck harvest. Initialized in 1958, the sampling reached national coverage in 1961, and is still running today. Age and sex identification material based on data from this project was published in 1992 (Carney 1992), and a "pre-study" in mallards was published back in 1960 (Carney \& Geis 1960). Moreover, cloacal examination is a commonly used method to sex juvenile waterfowl (Hochbaum 1942). This is, however, a technique most ringers are inexperienced with.

As part of a long-term ringing program of migratory waterfowl in Sweden, we have collected a large number of detailed photographs of the plumage of birds with known age and sex. The aim of this article is to investigate the feasibility of proposed age criteria (regarding plumage and bare parts) and to provide an accessible online photo repository for the use in field situations.

\section{Methods}

Ottenby Bird Observatory $\left(56^{\circ} 12^{\prime} \mathrm{N}, 16^{\circ} 24^{\prime} \mathrm{E}\right)$ is situated on the southernmost cape of the island of Öland in the Baltic Sea. Just north of the bird observatory, a specially designed duck trap is used for catching ducks for scientific purposes such as ringing and sampling for avian influenza A viruses. The trap is a 30 meters long and 7 meters wide steel construction covered with (soft) nylon mesh. Wild ducks can enter through funnel-shaped entrances on one side and are attracted to the trap by bait grain and semi-domestic mallards kept in a separate compartment. Once a day, ducks that have entered the trap are herded into a separate section where they are caught, placed in individual cardboard boxes, and taken to a nearby field lab. There, a ring of steel with an identification number is closed around the tarsus, and then the age and sex of the bird is determined (if possible). Biometrical data collected for ducks include length of wing (measured from the carpal joint to the tip of the longest primary on the closed wing), "bill-head" (measured from the tip of the bill to the back of the

Table 2. Number of photographically documented autumn mallards in each sex and age category. Antal gräsänder av olika kön och ålder som dokumenterats fotografiskt under hösten.

\begin{tabular}{lcccccccc}
\hline Age Alder & 1 cy & 2 cy & 3 cy & $4 c y$ & $5 c y$ & $6 c y$ & 7 cy & Total \\
\hline Male Hane & 37 & 10 & 8 & 6 & 6 & 4 & 1 & 72 \\
Female Hona & 36 & 4 & 4 & 3 & 0 & 0 & 0 & 47 \\
\hline
\end{tabular}


skull), and tarsus (measurement between the right angles of the tibiotarsus and the tarsometatarsus on one end, and the tarsometatarsus and the bent foot on the other). Most birds, including approximately one thousand mallards each year, are caught in the autumn (September-December), when Ottenby is used as a major stopover site for ducks and other birds.

This article is based on experience and pictures gathered by Ottenby Bird Observatory personnel working with the duck ringing project 2002-2015. We focused on characters that had previously been judged relevant for ageing ducks (Baker 1993, Boyd et al. 1975, Carney 1992, Carney \& Geis 1960, Mouronval 2014). Characters have been verified by documentation of birds with known age, being ringed as juveniles and recaptured at older ages. The examined photo material consists of 119 mallards of various ages (Table 2).

\section{Reliability test of age characters}

To test the reliability of different age characters, ten present or former ringers at Ottenby Bird Observatory took part in a questionnaire. Photographs of aged mallards were placed according to character. In the first set-up, for each sex, ten pictures of each of nine (previously described) age characters (Table 3) were randomly selected from the archive. The selected pictures were presented one by one and the participants were to decide whether each picture referred to a first calendar year (1cy) or adult $(2 \mathrm{cy}+)$ mallard. In this attempt, we aimed at determining the chance of correctly ageing a mallard from any single character. Therefore, $1 \mathrm{cy}$ birds referred to as adults were registered as incorrectly aged, even if they had completed post-juvenile moult and thus were adult according to plumage (not relevant for e.g. lesser, middle and greater coverts not included in the pre-breeding moult). In

Table 3. Summary of nine characters for four mallard age/sex categories. Swedish version below.

\begin{tabular}{|c|c|c|c|c|}
\hline Character & 1cy male & 2 cy+ male & 1cy female & 2 cy+ female \\
\hline Rectrices (RR) & $\begin{array}{l}\text { Retained juvenile } \\
\text { RR narrow, notched } \\
\text { at tip, brown with } \\
\text { buff edges and inter- } \\
\text { nal patterns. }\end{array}$ & $\begin{array}{l}\text { Broad and mainly } \\
\text { whitish-grey. Inter- } \\
\text { nal patterns faint, } \\
\text { but may be dark grey } \\
\text { and/or grizzled. }\end{array}$ & $\begin{array}{l}\text { Narrow, notched } \\
\text { at tip. Note ground } \\
\text { colour, shape and } \\
\text { distribution of inter- } \\
\text { nal patterns. }\end{array}$ & $\begin{array}{l}\text { Broad and of good } \\
\text { quality, black and } \\
\text { warm buff. Exten- } \\
\text { sive and irregular } \\
\text { internal patterns. }\end{array}$ \\
\hline Tertials (TT) & $\begin{array}{l}\text { Retained juvenile } \\
\text { TT narrow, worn and } \\
\text { dark brownish-grey. }\end{array}$ & $\begin{array}{l}\text { Broad, silvery-grey } \\
\text { fading into chestnut } \\
\text { and black on } \mathrm{T} 1-\mathrm{T} 2 \text {. }\end{array}$ & $\begin{array}{l}\text { Narrow, uniformly } \\
\text { brown and faded, } \\
\text { worn and frayed. }\end{array}$ & $\begin{array}{l}\text { Broad and grey, } \\
\text { T1-T2 have warm } \\
\text { brown edges on } \\
\text { outer vanes. }\end{array}$ \\
\hline Tertial coverts (TC) & $\begin{array}{l}\text { Narrow, worn and } \\
\text { frayed, rather uni- } \\
\text { formly dull brown. }\end{array}$ & $\begin{array}{l}\text { Broad, unfrayed, } \\
\text { outer TC grey at base } \\
\text { and chestnut at tip. }\end{array}$ & $\begin{array}{l}\text { Narrow and dark } \\
\text { brownish-grey with } \\
\text { buffish-white tips. }\end{array}$ & $\begin{array}{l}\text { Broad and fairly grey } \\
\text { (some warmer brown), } \\
\text { broad white tips. }\end{array}$ \\
\hline Greater coverts (GC) & $\begin{array}{l}\text { Narrow and fairly } \\
\text { pointed, weak bands, } \\
\text { seldom black on in- } \\
\text { ner vane of GC3. }\end{array}$ & $\begin{array}{l}\text { Broad and blunt- } \\
\text { tipped, neat and solid } \\
\text { black-and-white } \\
\text { band to GC2. }\end{array}$ & $\begin{array}{l}\text { Narrow and fairly } \\
\text { pointed, black is } \\
\text { fading in GC 3-6, } \\
\text { buffish-white tips } \\
\text { more common. }\end{array}$ & $\begin{array}{l}\text { Broad and blunt- } \\
\text { tipped, distinct black } \\
\text { usually present on } \\
\text { both vanes out to } \\
\text { GC3. }\end{array}$ \\
\hline $\begin{array}{l}\text { Median and lesser } \\
\text { coverts (MC \& LC) }\end{array}$ & $\begin{array}{l}\text { Dull grey-brown, } \\
\text { comparably more } \\
\text { worn, narrower at } \\
\text { base and less roun- } \\
\text { ded at tip. }\end{array}$ & $\begin{array}{l}\text { Grey-brown with an } \\
\text { obvious silvery hue, } \\
\text { organized, good qua- } \\
\text { lity, broad at base. }\end{array}$ & $\begin{array}{l}\text { Greyish-brown, } \\
\text { some with buff ed- } \\
\text { ging, worn, narrow } \\
\text { and pointed. }\end{array}$ & $\begin{array}{l}\text { Cold greyish cast, } \\
\text { some with buff ed- } \\
\text { ging. More likely to } \\
\text { have chestnut hue? }\end{array}$ \\
\hline $\begin{array}{l}\text { Primary coverts and } \\
\text { primaries (PC \& PP) }\end{array}$ & $\begin{array}{l}\text { PC narrow and poin- } \\
\text { ted, dull grey-brown } \\
\text { with grey edge. }\end{array}$ & $\begin{array}{l}\text { PC fairly rounded } \\
\text { and uniformly grey. } \\
\text { PP not heavily worn. }\end{array}$ & $\begin{array}{l}\text { PC narrow and poin- } \\
\text { ted, dull grey-brown. } \\
\text { PP heavily worn. }\end{array}$ & $\begin{array}{l}\text { PC broader and roun- } \\
\text { der with contrasting } \\
\text { grey outer vanes. }\end{array}$ \\
\hline Post-humerals (PH) & $\begin{array}{l}\text { Worn, narrow, dark } \\
\text { brownish-grey. }\end{array}$ & $\begin{array}{l}\text { Good quality, } \\
\text { broader and rounder, } \\
\text { grey. }\end{array}$ & $\begin{array}{l}\text { Narrow and dark } \\
\text { brownish-grey; adult } \\
\text { PH similar. }\end{array}$ & $\begin{array}{l}\text { Greyer, broader } \\
\text { and rounder than in } \\
\text { juveniles. }\end{array}$ \\
\hline Bill & $\begin{array}{l}\text { Greenish-yellow } \\
\text { with blackish area on } \\
\text { the ridge. }\end{array}$ & $\begin{array}{l}\text { Bright yellowish } \\
\text { except blackish nail } \\
\text { at the tip. }\end{array}$ & $\begin{array}{l}\text { Duller orange, indis- } \\
\text { tinct saddle, no (or } \\
\text { few) spots. }\end{array}$ & $\begin{array}{l}\text { Bright orange, } \\
\text { distinct saddle and } \\
\text { black spots. }\end{array}$ \\
\hline Feet & Dull orange. & Bright orange. & Dull orange. & Orange. \\
\hline
\end{tabular}


Tabell 3, forts

Sammanfattning av nio egenskaper för ålders- och könsbestämning av gräsänder. English version above.

\begin{tabular}{|c|c|c|c|c|}
\hline Karaktär & 1cy hane & 2 cy+ hane & 1cy hona & $2 c y+$ hona \\
\hline Stjärtpennor (RR) & $\begin{array}{l}\text { Kvarvarande } \\
\text { juvenila RR smala, } \\
\text { urnupna i spetsen, } \\
\text { bruna med gul- } \\
\text { bruna kanter och inre } \\
\text { mönster. }\end{array}$ & $\begin{array}{l}\text { Breda och till större } \\
\text { delen vitgrå. Inre } \\
\text { mönster otydligt, } \\
\text { men kan vara } \\
\text { mörkgrått och/eller } \\
\text { gråmelerat. }\end{array}$ & $\begin{array}{l}\text { Smala, hack i } \\
\text { spetsen. Notera } \\
\text { grundfärg, form och } \\
\text { utbredning av inre } \\
\text { mönster. }\end{array}$ & $\begin{array}{l}\text { Breda och av bra } \\
\text { kvalitet, svarta och } \\
\text { varmt gulbruna. } \\
\text { Omfattande och } \\
\text { oregelbundet inre } \\
\text { mönster. }\end{array}$ \\
\hline Tertialer (TT) & $\begin{array}{l}\text { Kvarvarande juve- } \\
\text { nila TT smala, slitna } \\
\text { och mörkt brunaktigt } \\
\text { grå. }\end{array}$ & $\begin{array}{l}\text { Breda, silvergrå, } \\
\text { övergående i kastan- } \\
\text { jebrunt och svart på } \\
\text { T1-T2. }\end{array}$ & $\begin{array}{l}\text { Smala, enfärgat } \\
\text { bruna och blekta, } \\
\text { slitna och fransiga. }\end{array}$ & $\begin{array}{l}\text { Breda och grå. T1- } \\
\text { T2 har varmt bruna } \\
\text { kanter på ytterfanen. }\end{array}$ \\
\hline Tertialtäckare (TC) & $\begin{array}{l}\text { Smala, slitna och } \\
\text { fransiga, ganska } \\
\text { enfärgat matt bruna. }\end{array}$ & $\begin{array}{l}\text { Breda, ofransade, } \\
\text { yttre TC, grå vid } \\
\text { basen och kastanje- } \\
\text { bruna i spetsen. }\end{array}$ & $\begin{array}{l}\text { Smala och mörkt } \\
\text { brungrå med gulbru- } \\
\text { na till vita spetsar. }\end{array}$ & $\begin{array}{l}\text { Breda och tämligen } \\
\text { grå (somliga varmt } \\
\text { bruna), breda vita } \\
\text { spetsar. }\end{array}$ \\
\hline Större täckare (GC) & $\begin{array}{l}\text { Smala och rätt } \\
\text { spetsiga, svaga band, } \\
\text { sällan svarta på } \\
\text { innefanet av GC3. }\end{array}$ & $\begin{array}{l}\text { Breda och trubb- } \\
\text { spetsade, tydligt och } \\
\text { kraftigt svart och vitt } \\
\text { band till GC2. }\end{array}$ & $\begin{array}{l}\text { Smala och rätt spetsi- } \\
\text { ga, svart mattare hos } \\
\text { GC } 3-6 \text {, gulbruna till } \\
\text { vita spetsar vanligare. }\end{array}$ & $\begin{array}{l}\text { Breda och trubbspet- } \\
\text { sade, tydligt svart } \\
\text { på båda fanen ut till } \\
\text { GC3. }\end{array}$ \\
\hline $\begin{array}{l}\text { Mellersta och mindre } \\
\text { täckare (MC \& LC) }\end{array}$ & $\begin{array}{l}\text { Matt gråbruna, jäm- } \\
\text { förelsevis mer slitna, } \\
\text { smalare vid basen } \\
\text { och mindre rundad } \\
\text { spets. }\end{array}$ & $\begin{array}{l}\text { Gråbruna med tydlig } \\
\text { silverton, välord- } \\
\text { nade, god kvalitet, } \\
\text { breda vid basen. }\end{array}$ & $\begin{array}{l}\text { Gråbruna, somliga } \\
\text { med gulbruna kanter, } \\
\text { slitna, smala och } \\
\text { spetsiga. }\end{array}$ & $\begin{array}{l}\text { Kyligt gråaktig } \\
\text { anstrykning, somliga } \\
\text { med gulbruna kanter. } \\
\text { Oftare kastanjebrun } \\
\text { anstrykning? }\end{array}$ \\
\hline $\begin{array}{l}\text { Handtäckare och hand- } \\
\text { pennor (PC \& PP) }\end{array}$ & $\begin{array}{l}\text { PC smala och spet- } \\
\text { siga, matt gråbruna } \\
\text { med grå kanter. }\end{array}$ & $\begin{array}{l}\text { PC tämligen rundade } \\
\text { och enhetligt grå. PP } \\
\text { ej hårt slitna. }\end{array}$ & $\begin{array}{l}\text { PC smala och spet- } \\
\text { siga, matt gråbruna. } \\
\text { PP slitna. }\end{array}$ & $\begin{array}{l}\text { PC bredare och run- } \\
\text { dare med kontraste- } \\
\text { rande grå ytterfan. }\end{array}$ \\
\hline Posthumeraler (PH) & $\begin{array}{l}\text { Slitna, smala, mörkt } \\
\text { brunaktigt grå. }\end{array}$ & $\begin{array}{l}\text { Hög kvalitet, bredare } \\
\text { och rundare, grå. }\end{array}$ & $\begin{array}{l}\text { Smala och mörkt } \\
\text { brunaktigt grå; adul- } \\
\text { tas PH lika. }\end{array}$ & $\begin{array}{l}\text { Gråare, bredare } \\
\text { och rundare än hos } \\
\text { juveniler. }\end{array}$ \\
\hline Näbb & $\begin{array}{l}\text { Grönaktigt gul med } \\
\text { svart på näbbryggen. }\end{array}$ & $\begin{array}{l}\text { Lysande gul förutom } \\
\text { svart nagel i spetsen. }\end{array}$ & $\begin{array}{l}\text { Mattare orange, } \\
\text { otydlig sadel, inga } \\
\text { eller få fläckar. }\end{array}$ & $\begin{array}{l}\text { Lysande orange, tyd- } \\
\text { lig sadel och svarta } \\
\text { fläckar. }\end{array}$ \\
\hline Fötter & Matt orange & Lysande orange. & Matt orange. & Orange. \\
\hline
\end{tabular}

the second set-up, 20 individuals of each sex were selected and pictures of all the nine characters were presented for each of them. This was done in order to quantify the possibility of ageing mallards correctly with all characters at hand.

\section{Results and Discussion}

\section{Sexing}

Young mallards are generally possible to sex by field characters already before they have become independent from their mother. Females have an orange bill with a variable blackish pattern, often covering a large part of the upper mandible. In the typical case, the dark area starts close to the base of the bill (often leaving a narrow, clean orange area next to the feathering), covers the nostrils and reaches to about one centimeter short of the blackish bill tip. Adult (i.e. 2 cy+) females acquire a more distinct blackish pattern and sometimes extensive blackish spotting. From the age of one month, young males develop a greenish-yellow bill, which often appear plain with a (less extensive) dark area on the central upper ridge. Adult birds are always easy to sex according to bill pattern, although genetically depleted feral birds (and perhaps other?) can deviate from the normal patterns. Males in eclipse plumage may appear superficially similar to females, but differentiate from females by blacker crown and more greyish face and neck.

As the post-juvenile moult progresses, males and females are easily separated by plumage differences. The green head, white necklace, brown 
breast, grey body, and black rear of males clearly distinguish them from the camouflaged plumage of females, with its buff and tawny-brown background colours, heavily marked with various black patterns. The wing pattern is, however, quite similar between the sexes, especially in 1cy birds. In general, females have browner wing coverts, some with obvious buffish edging (rare in young males, absent in adult males). The black tips to greater coverts are on average broader in males, but the white wingbar on greater coverts is longer in females and reaches the tertial coverts, whereas it barely continues beyond the secondaries in males. Only males attain grey and vermiculated scapulars, and innermost underwing coverts are broadly barred in females, but finely vermiculated in males.

Males are on average larger and heavier than females (Table 4). Within the sexes, adult mallards have on average slightly longer wings and are heavier than 1cy birds (Table 4).

\section{Age characteristics in autumn}

Young mallards are most easily recognised by the presence of juvenile tertials and rectrices. These are often noticeably narrow, frayed, and faded, although some late broods may still have quite fresh tertials and tail feathers at least until mid-autumn (October). Further, tertials and rectrices show distinctive character differences between juvenile and adult males and females, respectively. Tertial coverts are usually also quite a useful character for ageing. Juveniles start to moult TT and RR from October onwards, after which ageing gets more complicated and other characters need to be examined more closely. All features are subject to individual variation, so ageing should always be based on a summary of characters.
Males

With the pre-breeding moult, both 1cy and adult mallard males attain their species-distinctive metallic-green head that has earned the mallard its colloquial name "green-headed duck" in several languages (e.g. Chinese and Afrikaans). Although not very useful as a character, young males often retain a few juvenile feathers and thus look less "smashingly" green.

The bill is a somewhat more reliable feature, as young males tend to have a dull greenish-yellow bill with a blackish area on the ridge. In contrast, adults generally have a plain yellowish bill, except for the blackish nail at the tip. However, some young males approach spotless yellowish bills and a few adult males may show black patterns on a greenish-tinged background.

Feet colour is quite variable and should only be used as a supplement to other features. 1cy males often still have dull orange legs by late autumn, while most adults have acquired a richly orange colouration.

Central tail feathers (generally 2-3 pairs) of juvenile males are quite uniformly brownish-black with buff edging (Figure 3). Outer rectrices have slightly lighter centra, being brown or greyishbrown with broken, female-like, internal patterns. They are narrower than corresponding feathers in adults, and often frayed and notched at the tip. By October, many juveniles have moulted and attained a mainly post-juvenile (i.e. adult) tail (Figure 4), although some juvenile rectrices may be kept throughout the winter. In adults, rectrices are broader and predominantly pale grey, some having grey internal patterns (more or less faint). Central 2-3 pairs (actually R3-5 on each side, as R $1-2$ are black and upcurled) may have blackish-grey centra and can then be quite similar to juvenile tail feath-

Table 4. Mean \pm SD values of wing length, bill-head length, tarsus length, and body mass for four different age/ sex categories of mallards caught at Ottenby, SE Sweden, in autumn (September-December) 2002-2014. Medelvärden $\pm S D$ för kroppsmått och vikt för olika kön och ålder under hösten vid Ottenby.

\begin{tabular}{lcccc}
\hline $\begin{array}{l}\text { Age/sex category } \\
\text { Alder/kön }\end{array}$ & $\begin{array}{c}\text { Wing }(\mathrm{mm}) \\
\text { Vinglängd }\end{array}$ & $\begin{array}{c}\text { Bill-head }(\mathrm{mm}) \\
\text { Näbblängd }\end{array}$ & $\begin{array}{c}\text { Tarsus }(\mathrm{mm}) \\
\text { Tars }\end{array}$ & $\begin{array}{c}\text { Body mass }(\mathrm{g}) \\
\text { Vikt }\end{array}$ \\
\hline 1cy female hona & $265.4 \pm 6.2$ & $106.0 \pm 2.8$ & $54.8 \pm 1.8$ & $988.0 \pm 105.1$ \\
& $(\mathrm{n}=2016)$ & $(\mathrm{n}=1477)$ & $(\mathrm{n}=1476)$ & $(\mathrm{n}=2024)$ \\
& $270.1 \pm 6,3$ & $106.8 \pm 2.8$ & $55.2 \pm 1,9$ & $1028.0 \pm 114.2$ \\
2cy+ female hona & $(\mathrm{n}=564)$ & $(\mathrm{n}=570)$ & $(\mathrm{n}=570)$ & $(\mathrm{n}=649)$ \\
& $280.9 \pm 6.7$ & $113.7 \pm 2.9$ & $57.6 \pm 1.9$ & $1147.7 \pm 126.5$ \\
1cy male hane & $(\mathrm{n}=2674)$ & $(\mathrm{n}=2017)$ & $(\mathrm{n}=2017)$ & $(\mathrm{n}=2675)$ \\
& $287.0 \pm 7.3$ & $114.4 \pm 3.1$ & $58,0 \pm 2.0$ & $1220,0 \pm 121.0$ \\
2cy+ male hane & $(\mathrm{n}=1177)$ & $(\mathrm{n}=1059)$ & $(\mathrm{n}=1058)$ & $(\mathrm{n}=1158)$ \\
& & & & \\
\hline
\end{tabular}




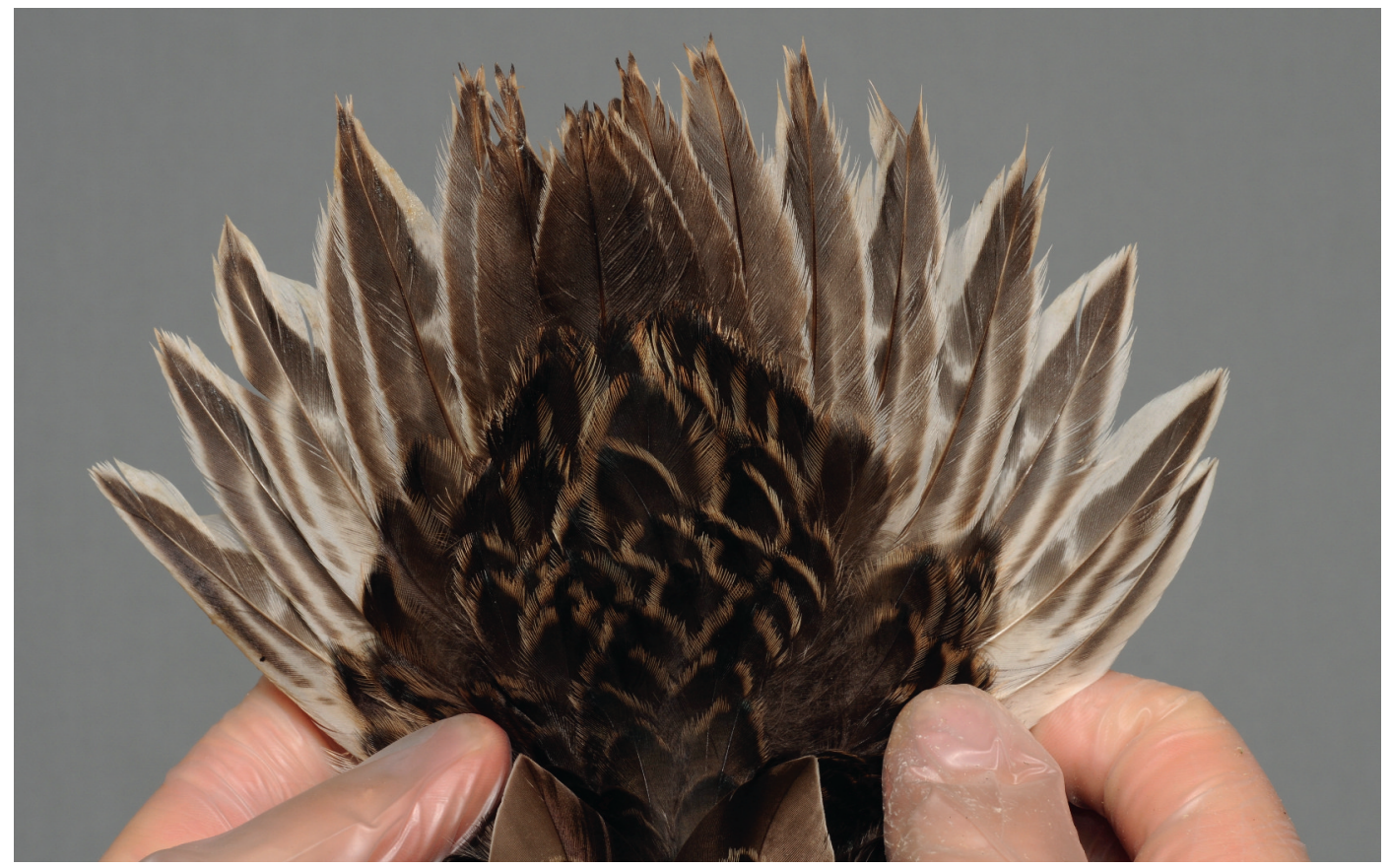

Figure 3. 1cy male, September. Typical juvenile tail with rectrices that are narrow, worn, notched at the tip, and mainly brownish in colour with buffish edging. All except central 2-3 pairs show broken internal patterns.

Typisk ung hane i september med stjärtpennor smala, urnupna och tandade $i$ spetsen, till större delen bruna med ljusare kanter.

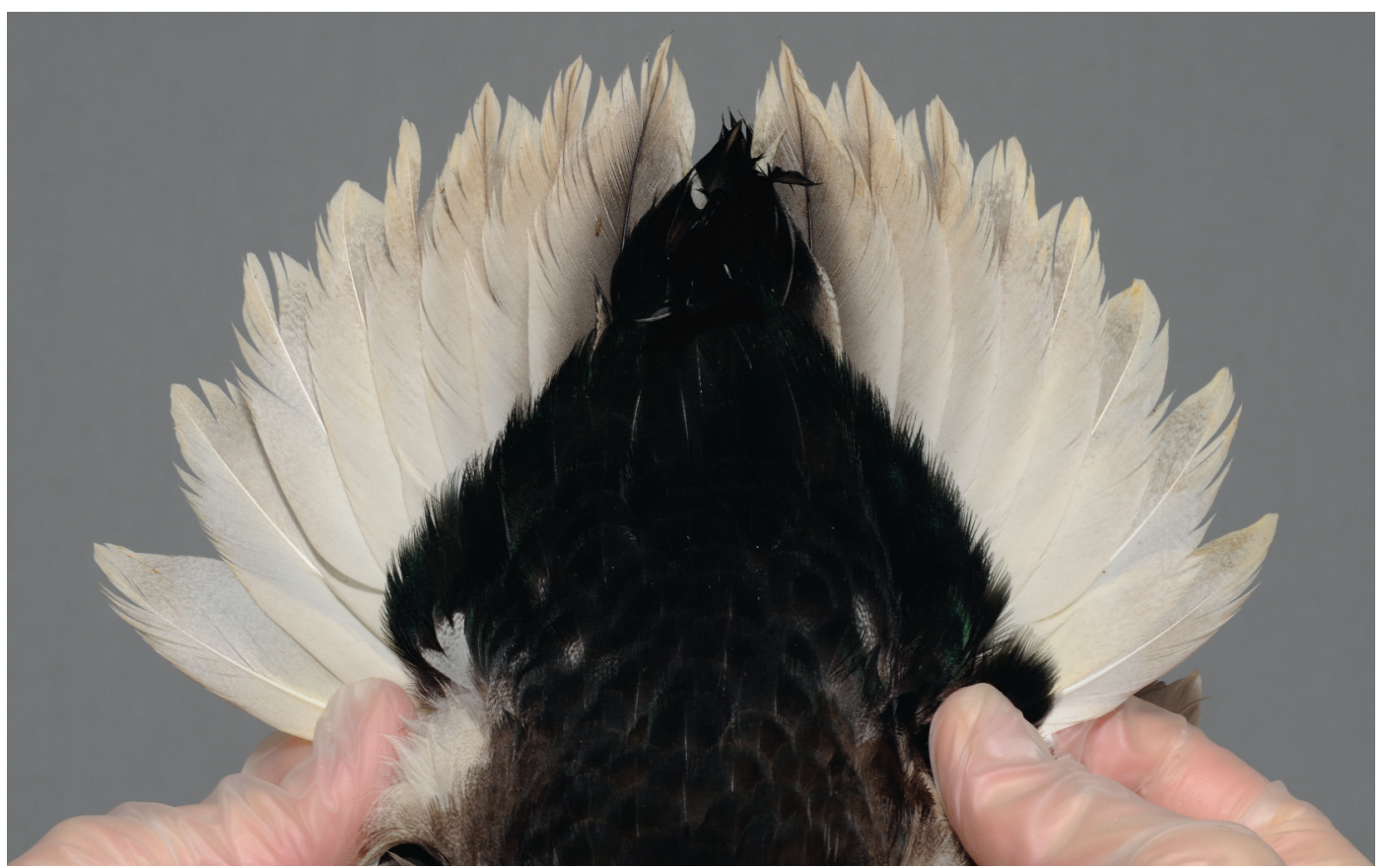

Figure 4. 1cy male, November. The whole tail is post-juvenile and this individual is, therefore, identical to an adult male by this character. Note broader shape, better quality, lack of notching and heavy abrasion, and no brown colouration.

Juvenil hane $i$ november efter ruggning av stjärten. Denna individ är därför identisk med en adult hane i denna karaktär. Notera bredare form, högre kvalitet, inga urnupna spetsar, ingen kraftig förslitning och inget brunt. 


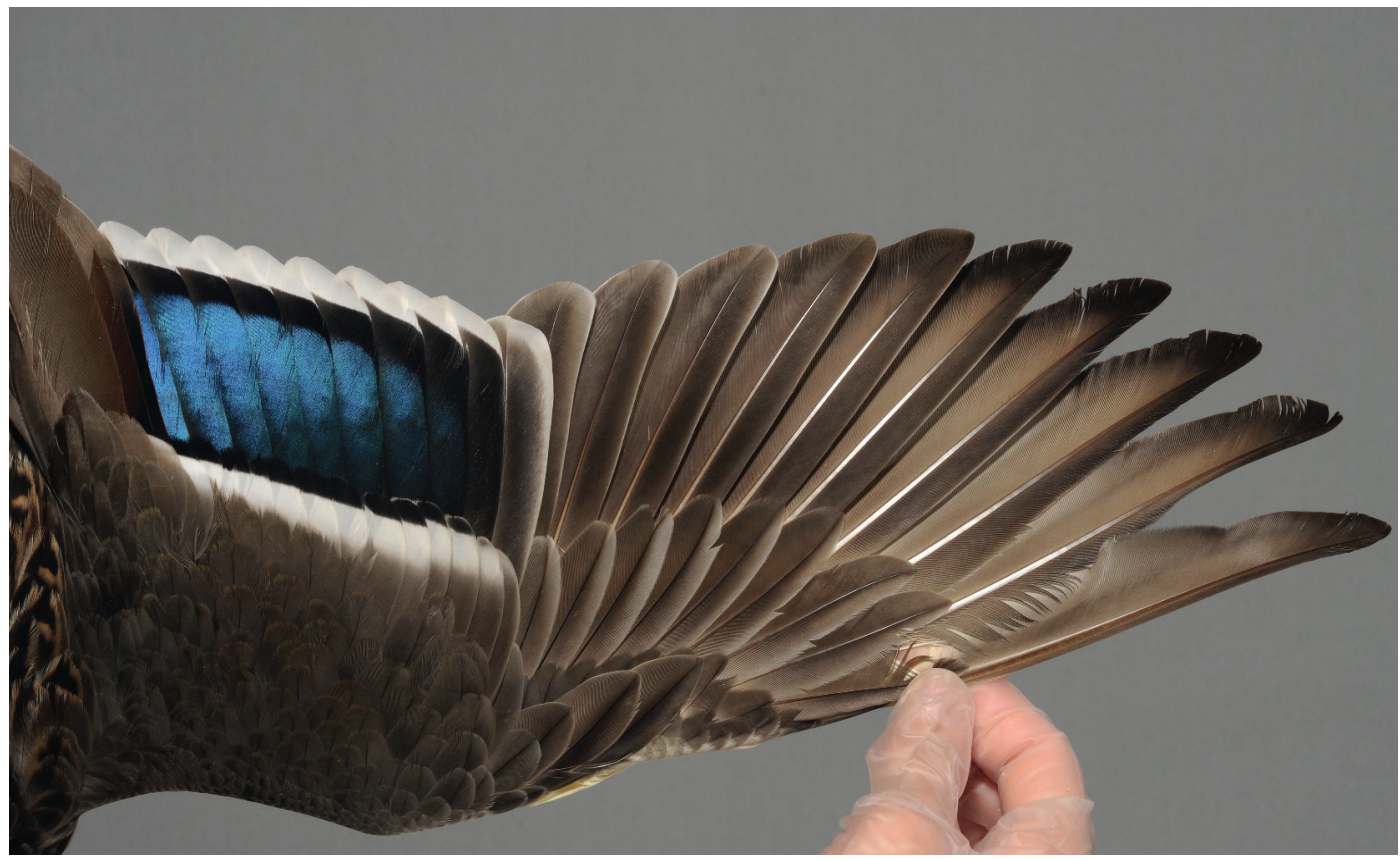

Figure 5. 1cy male, September. A quite typical wing of a juvenile male. Lesser and median coverts, as well as primary coverts and primaries, are dull brownish. The latter show heavy signs of wear. Buffish tips to MC and LC do not occur in adults. Typisk vinge av juvenil hane i september. Mindre och mellersta täckare är liksom handtäckare och handpennor mörkt brunaktiga. Handpennorna kraftigt slitna. Ljusbruna spetsar på MC och LC saknas hos adulta.

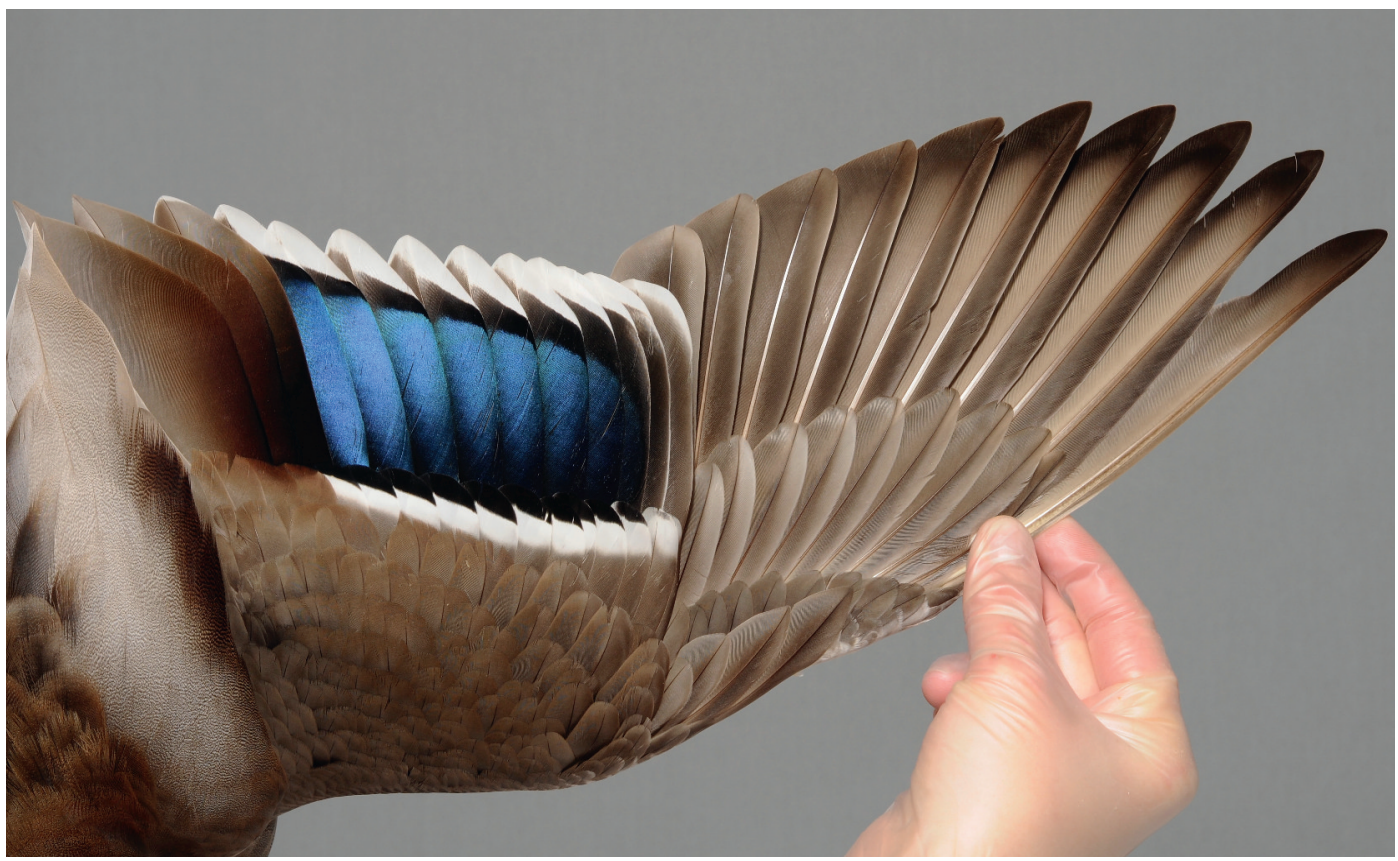

Figure 6. 2cy+ male, October. A typical and easily identified adult, showing a grey cast to the whole wing. Note broad, rounded, quite uniformly silvery-grey PC, as well as broad and blunt-tipped GC with full black tips reaching the second outermost feather. $2 c y+$ hane $i$ oktober. En typiskt och lätt åldersbestämd hane. Notera breda, rundade och enhetligt silvergrå PC, liksom breda och rundspetsade GC med helt svarta spetsar ut till näst yttersta fjädern. 


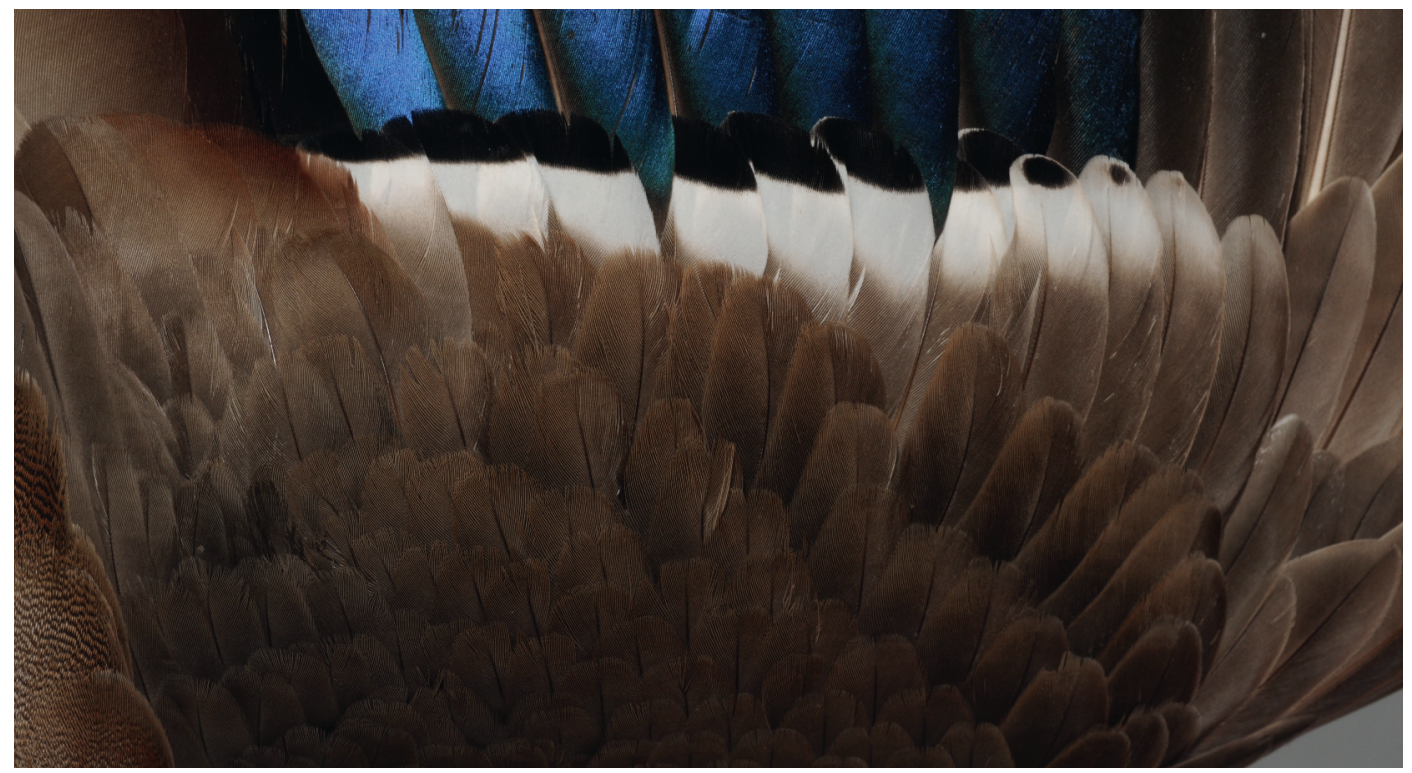

Figure 7. 1cy male, October. Juvenile MC and LC are dull brown and often give an unstructured appearance. GC and MC are slightly narrower and more pointed, not widening as much towards the base as in adults. The black GC band gets much reduced in the outer part of the arm and is often not present at all in GC1-3, or present on the outer vane of the feather only. lcy hane i oktober. MC och LC är matt bruna och ger ofta ett ostrukturerat intryck. GC och MC är något smalare och spetsigare och blir inte bredare mot basen som hos en adult. Det svarta bandet hos GC reduceras i den yttre delen av armen och saknas ofta hos GC1-3 eller finns bara på ytterfanet.

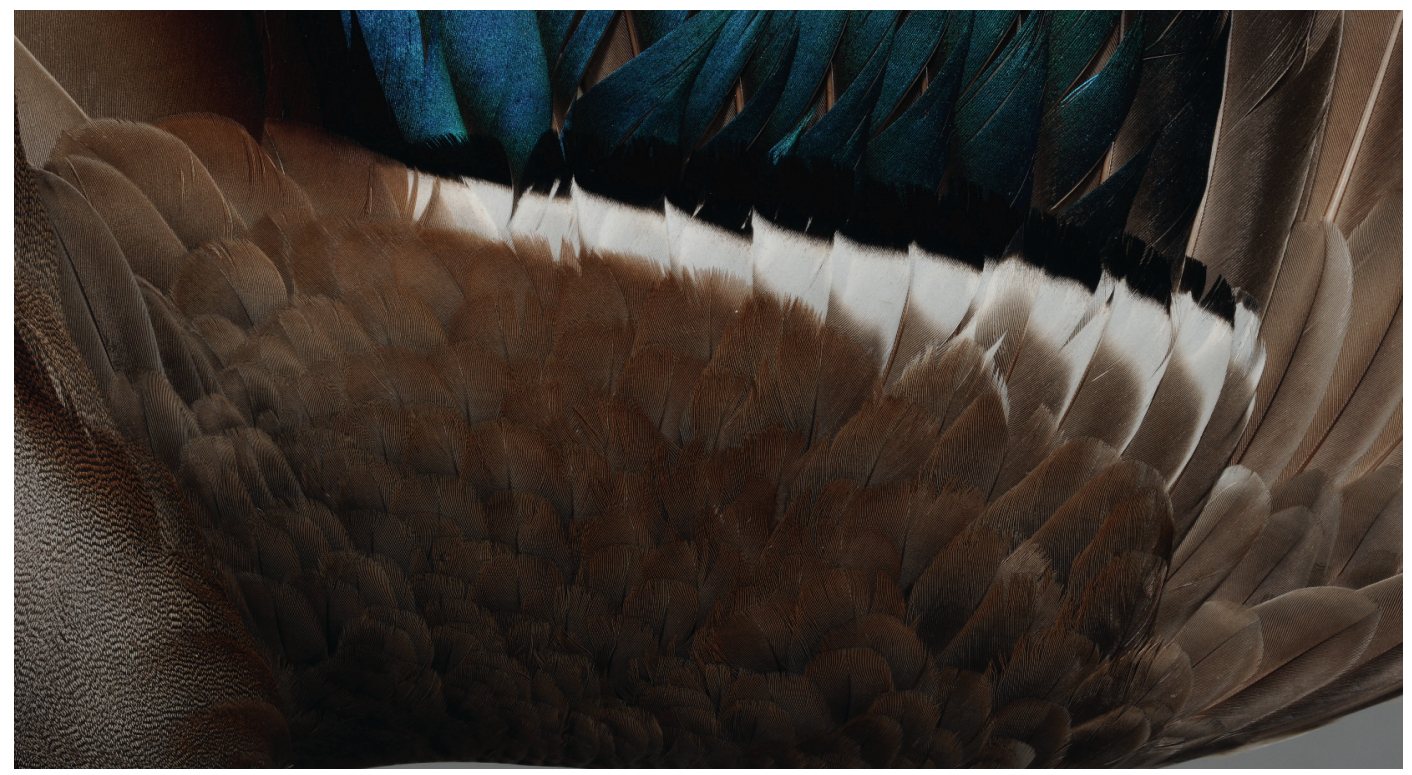

Figure 8. 2cy+ male, December. Adult GC are tipped distinctly black (on both vanes) further out than on juvenile GC, in this case to GC2 (even GC1 has black tip, which is unusual). The black-and-white generally forms a fairly neat line (although slightly irregular in this individual) and adults usually show more sharply demarcated borders to grey base of GC compared to juveniles. Note chestnut-brown LC and MC and also that outer MC are nicely rounded and widely broadening towards the base.

$2 c y+$ hane i december. Spetsarna hos GC är tydligt svarta längre ut på båda fanen än hos juvenil, i detta fall till GC2 (till och med GCl har svart spets, vilket är ovanligt). Gränsen mellan svart och vitt är vanligen rak men på just denna individ något orgelbunden. Adulta har vanligen skarpare gräns mot den grå basen hos GC än juveniler. Notera kastanjebuna LC och MC samt även att yttre MC är vackert rundade och bredare mot basen. 


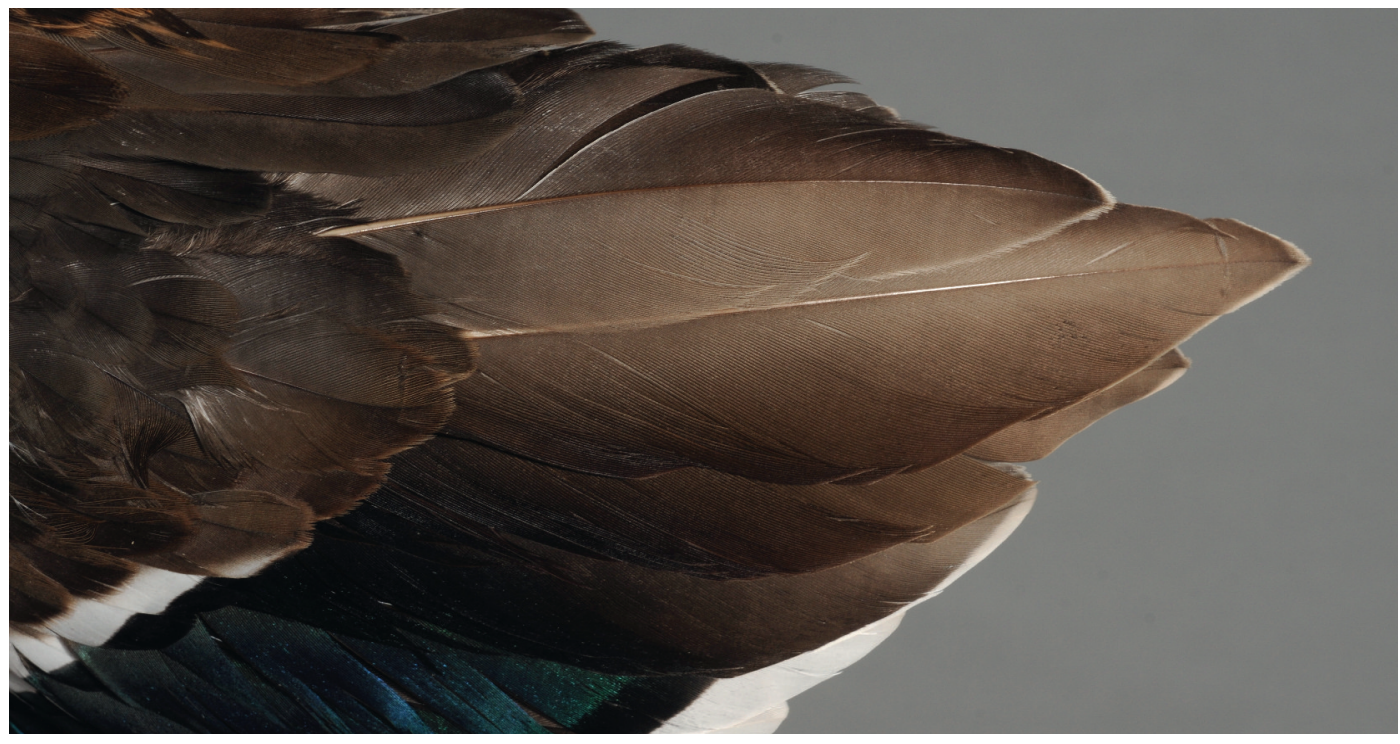

Figure 9. 1cy male, September. Juvenile tertials are narrower compared to post-juvenile TT and often abraded. Further, they have a more uniform brownish ground colour, lacking the obvious silvery-grey hue of adults. The pale tips and edges may disappear with wear. Juvenile tertial coverts are narrower, more pointed, browner, and usually more frayed compared to adults. TC may be edged buff (as in this individual) and some may even show a blackish subterminal band inside.

lcy hane i september. De juvenila tertialerna är smalare än hos adulta och ofta nerslitna. De är dessutom mera enfärgat bruna och saknar den tydligt silvergrå tonen hos adulta. De ljusa spetsarna och kanterna kan försvinna genom förslitning. De juvenila tertialtäckarna är smalare, spetsigare, brunare och vanligen mer slitna än hos adulta. TC kan ha gulbruna kanter (som hos denna individ) och somliga kan till och med uppvisa ett svartaktigt subterminalt band.

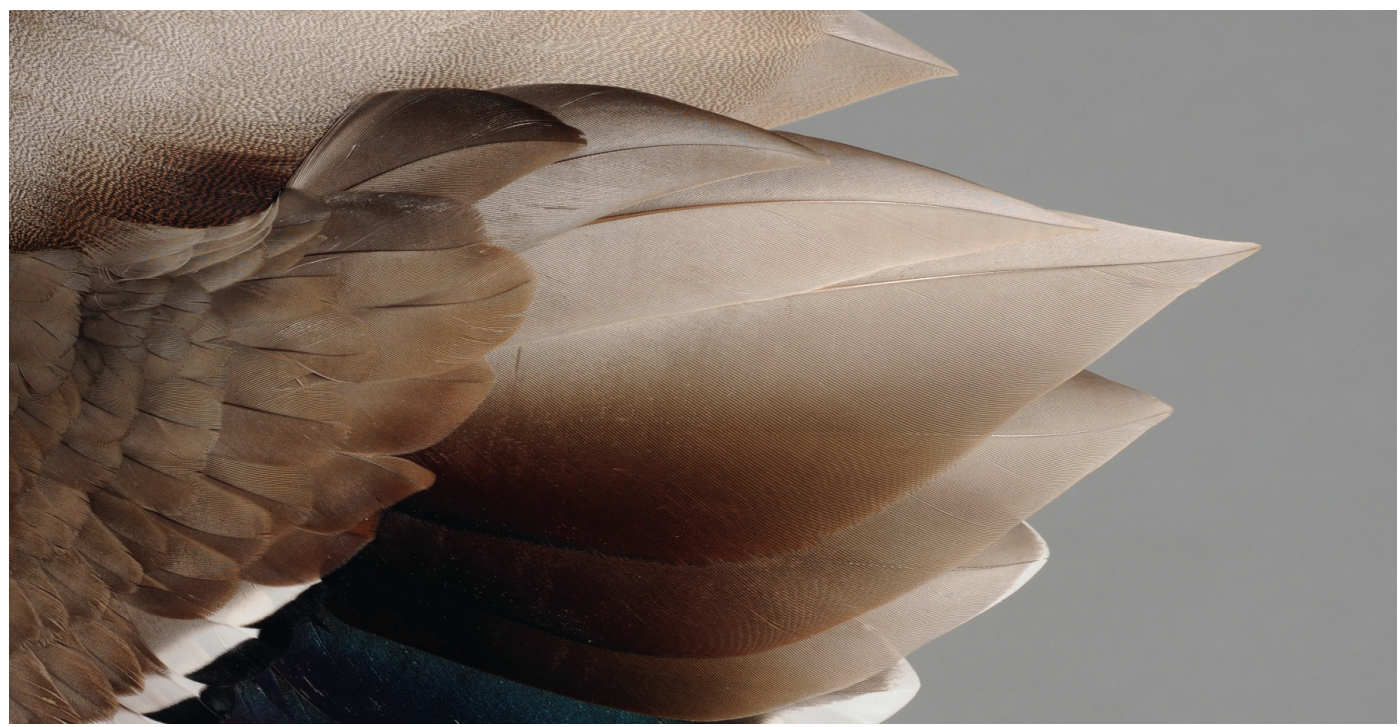

Figure 10. 2cy+ male, October. Adult tertials have a silvery-grey ground colour, fading towards blackish on inner web of T3 and T4, and towards warm brown and blackish on outer web of T1 and T2. Adult tertials are broader and generally show less signs of wear compared to juvenile TT. Adult TC are broad and grey, the outer TC usually broadly tipped chestnut, hence showing much more contrast than TC of juveniles.

$2 c y+$ hane i oktober. Adulta tertialer har silvergrå grundfärg, som övergår i svart på innerfanet av T3 och T4 samt mot varmt brunt och svartaktigt på ytterfanet av T1 och T2. Adulta tertialer är bredare och visar vanligen mindre förslitning än hos juvenila. Adulta TC är breda och grå, och de yttre TC har vanligen breda kastanjebruna spetsar och är därför kontrastrikare än de juvenila TC. 
ers. Adult RR are, however, different in quality and shape, much less brown in colour, and much more broadly edged whitish-buff.

In terms of wing colour, juvenile males (until complete wing moult at about one year of age) most often give a rather dull greyish-brown impression (Figure 5), while typical adult wings have a mainly greyish appearance with silvery-grey cast to primary coverts, primaries, and wing coverts (Figure 6). Adult PC are typically quite uniformly coloured and often stand out as the palest area. In juveniles, the centre of each primary covert is duller grey-brown in contrast to grey edge of outer vane, but this is also the case in many adults. Adult PC are more often fairly rounded, whereas PC of juveniles often are narrow and pointed. Adult PP are less often heavily abraded.

Adult median and lesser wing coverts may give a more homogeneous, neat and robust impression, while the wing covert area of juveniles often appears unorganized. This is probably related to the circumstance that juvenile MC generally show heavier signs of wear (due to poorer quality). MC of juveniles are also slightly narrower, less rounded (more angular), and less broadening towards the base compared to adults (Figure 7 and Figure 8, respectively). The ground colour of 1 cy birds is dull grey-brown compared to grey-brown with an obvious silvery hue in typical adults (Figure 6). Both juvenile and adult males show some warmer brown MC and LC, warmest in some adults that tend to go towards clear chestnut (Figure 8). Juvenile median coverts may show pale edging, which is never the case in adult males.

As with MC, juvenile greater coverts often appear narrower than subsequent generations. The black pattern at tips of GC varies within and among individuals, so this character should be used with care, but black on both inner and outer vanes generally extends further out in the wing, often reaching GC2, in adult males (Figure 8). Juveniles have more irregular black markings on outer $\mathrm{GC}$, and have quite often no black present on inner vane of GC3 (Figure 7). The white bar on GC is generally sharper and more neatly demarcated in adults, often reaching all the way out to GC1 (Figure 8). Both black and grey borders often appear vague and irregular in juveniles, and the white bar almost always turns diffuse (grey) on GC1-2 (Figure 7).

Juvenile male tertials are rather narrow and dark brownish-grey, lacking crisp grey colouration, and often have a pale buffish tip and edges (Figure 9). Adult tertials are broader and usually show less signs of wear (Figure 10). The ground colour is silvery-grey, fading into warm brown and black on outer vane of T1 and T2 (adjacent to the blue patch, i.e. the speculum, on SS). On adult T3 and T4, the grey fades into blackish towards the body (inner vane), although T4 is sometimes almost uniformly blackish-grey.

Moulted (i.e. adult) tertial coverts are broader and unfrayed, being of better quality compared to juvenile TC. Ground colour differences between juvenile and adult birds are similar to MC and LC, i.e. juvenile $\mathrm{TC}$ are rather homogeneously dull brown (Figure 9), whereas adult TC are greyer (Figure 10). Inner TC are usually duller, darker, and browner in both age categories. Typical outer TC of adults show grey bases contrasting to warm brown or chestnut tips, making them distinct from juvenile coverts. However, some adults have duller $\mathrm{TC}$, and some juveniles show adult-like TC with chestnut tips.

Juvenile male post-humerals are narrow and dark brownish-grey, lacking solid grey colouration. Typical adults show grey, broader, and rounder PH. As with other feather groups (e.g. MC, TT and $\mathrm{TC}$ ), juvenile $\mathrm{PH}$ are of poorer quality than corresponding adult feathers and therefore often show stronger signs of wear.

Scapulars of juvenile males are "female-patterned", whereas they are silvery-grey with dark vermiculations in adult males, some of which have warm dark-brown tips or outer/inner web (but still vermiculated). In adult eclipse plumage, the scapular area turns female-like again, but there are always some greyish and vermiculated feathers present. It may, however, be difficult to judge whether a bird is a young male that has acquired its first adult scapulars, or an adult eclipse male. Generally, juvenile feathers in the scapular area have darker and more solid centra (similar differences as between juvenile and adult female RR).

\section{Females}

The bill patterns of female mallards show much variation, but there are some general features to support other, more reliable, age characters. Many young females have dull orange bills (Figure 11), whereas most adult females have a bright yelloworange colour to the bill (Figure 12). As aforementioned, females have a blackish saddle, most often reaching from close to the base and falls less than a centimeter short of the equally blackish nail at the tip. The saddle is, however, very variable in both shape and intensity. Some females have diffuse and/or small saddles, whereas others have distinct and/or extensive ones. Adult females often show 


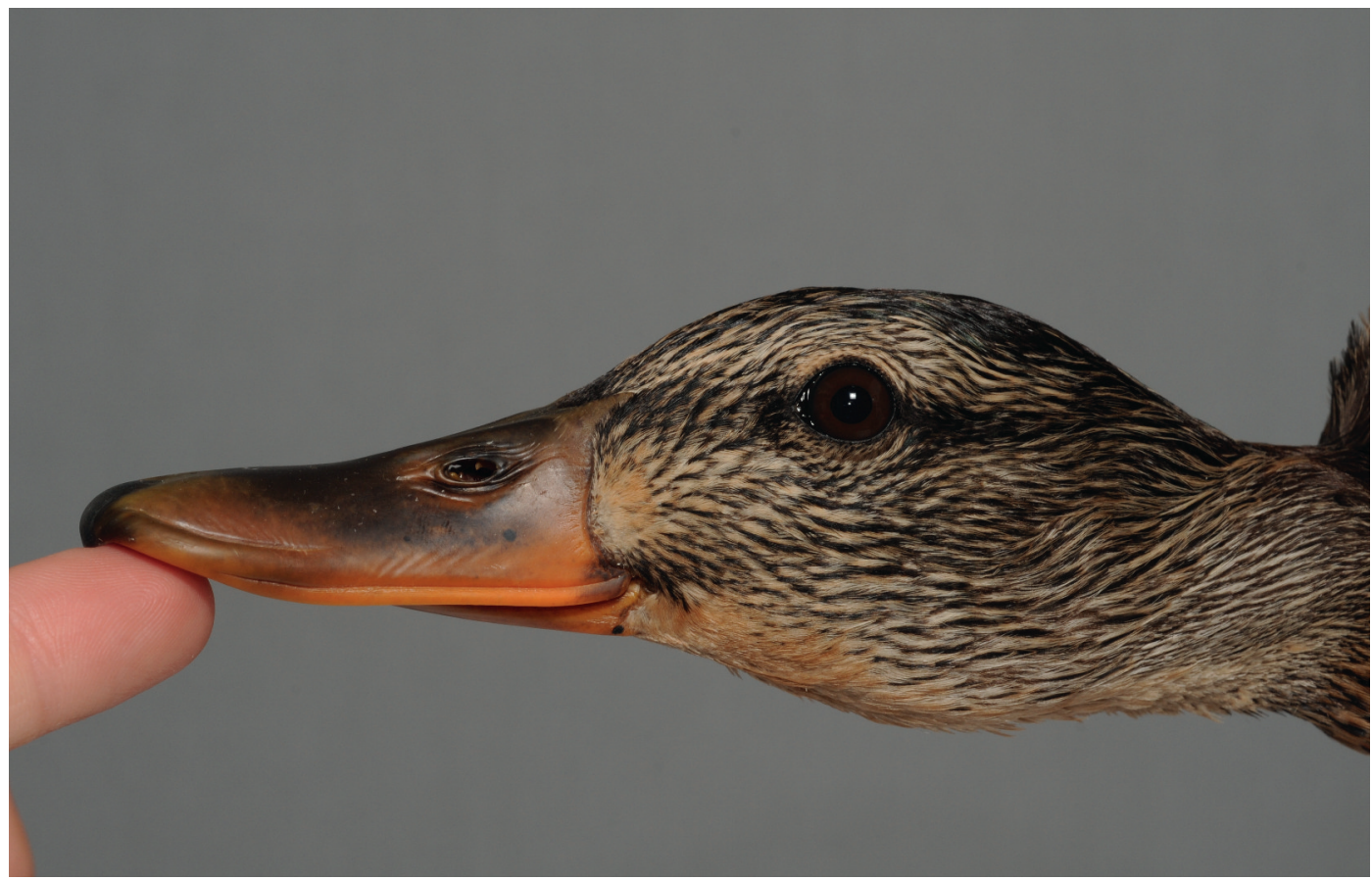

Figure 11. 1cy female, September. The female bill pattern is rather variable. Juveniles usually lack dark spots and show a dull orange colour, but these characters should only be used as a supplement to more important features.

lcy hona i september. Honornas näbbmönster varierar. Ungfåglarna saknar vanligen fläckar och är matt orange. Dessa karaktärer ska dock bara användas i kombination med andra viktigare karaktärer.

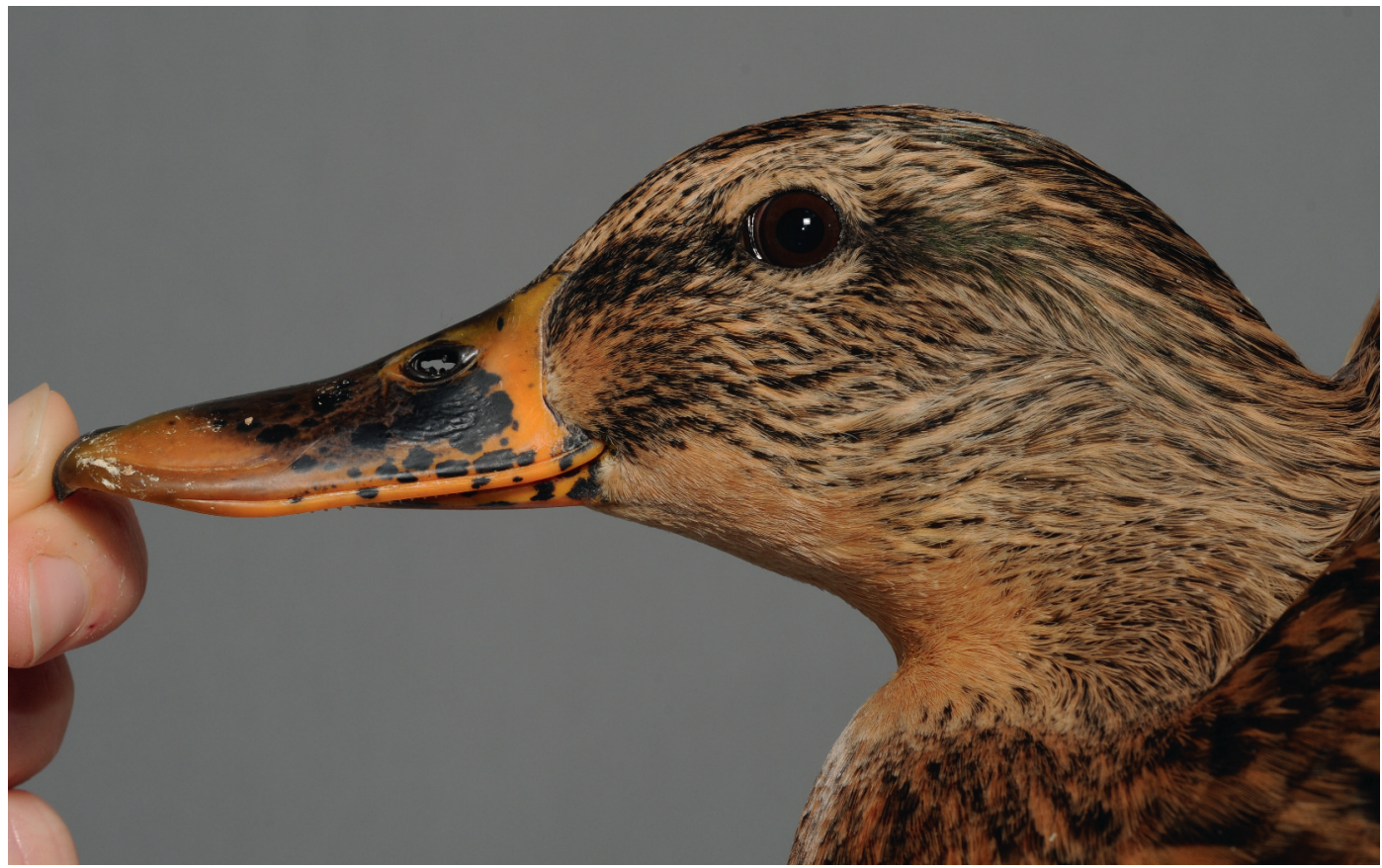

Figure 12. 2cy+ female, October. Adult females often show distinct blackish spots and a bright yellow-orange colour of the bill. $2 c y+$ hona i oktober. Adulta honor har ofta tydliga svarta fläckar och en klart gul-orange näbb. 
extensive blackish spotting (Figure 12), usually most obvious at the sides of the bill. Typical juveniles have a less distinct blackish saddle and lack obvious spotting (Figure 11).

There is a slight average difference in iris colouration between $1 \mathrm{cy}$ and adult females, as some young birds have very dark blackish-brown eyes. However, many 1 cy females have already by their first autumn acquired the lighter brown iris usually seen in adults.

Adult females show on average a deeper orange feet colour compared to pale orange in 1cy birds, although this is less distinctive than in males. Young birds with a rich colouration are inseparable from adults.

Juvenile female tail feathers are narrow, usually obviously worn, and have a notched tip. Typically, a blackish (mainly brown when worn) internal pattern covers most of the feather centre and runs all the way to the tip along the shaft (Figure 13). Especially the outer rectrices often present a double internal pattern: basally a narrow dark core along the shaft surrounded by a buff frame, which in turn is enclosed by the main dark area, followed by buff edges. The variation is large, though. Some juvenile females show only a narrow pale core enclosed by a dark area and buff edges, and some are almost entirely dark with just a narrow pale edge. The latter pattern is most common on central pairs of RR.

Adult female tail feathers are broader and of better quality. Pale internal patterns are extensive and quite irregular in shape, often cutting through the whole feather more or less horizontally (Figure 14). Borders to dark areas often appear more diffuse. The dark may (narrowly) reach the tip along the shaft, but RR of many adult females are broadly pale-tipped. When fresh, the ground colour of RR is much blacker and warm buff compared to the brownish-black and pale buff of juveniles. However, this contrast can be surprisingly difficult to detect in some individuals. The central pair of RR may show similarity to the juvenile pattern of al-

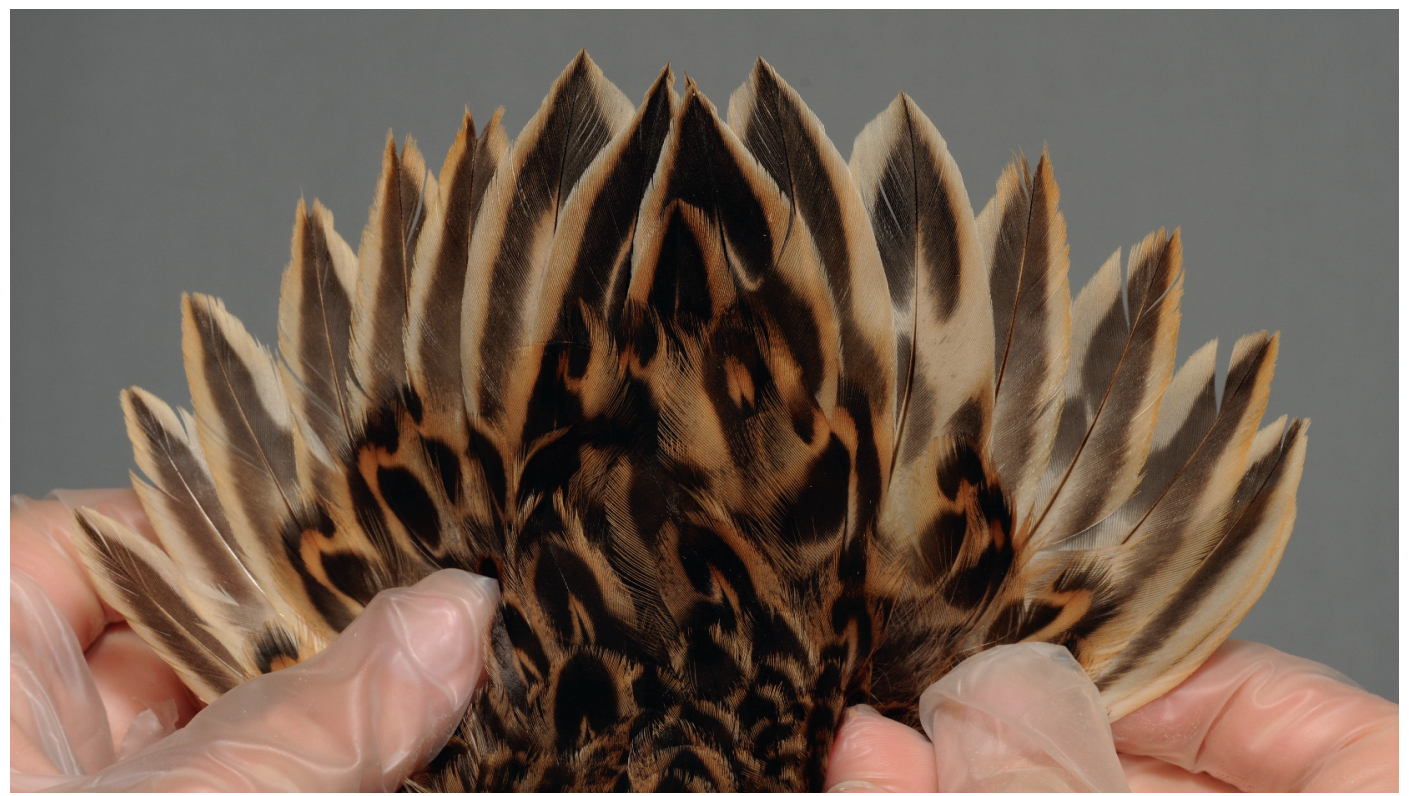

Figure 13. 1cy, female October. This tail looks fairly fresh, but retained juvenile feathers are narrow and distinctly notched. The dark internal patterns are distinctly set off, cover most of each feather centre, and run along the shaft all the way to the tip/ notch. The post-juvenile moult has started from the central pair, moulted feathers being broader, fresher, and lack notching. This is most easily seen in the third fully grown post-juvenile RR on the right-hand side, also showing a fairly horizontal pale area across the entire feather. The dark colour is obviously blacker compared to brownish in the retained RR. Usually, fresh adult feathers show warmer buff colouration as well.

1cy hona i oktober. Den här stjärten ser fräsch ut, men innehåller två generationer stjärtpennor. De juvenila är smala och tydligt urnupna i spetsen. Vidare är de mörka partierna tydligt avsatta, täcker större delen av fjädercentrum och löper längs spolen hela vägen till spetsen. Den postjuvenila ruggningen har påbörjats från stjärtens mitt. De nya (adulta) pennorna är bredare, fräschare och saknar urnypning i spetsen. Detta ses enklast hos den tredje inruggade pennan på höger sida, som också uppvisar ett horisontellt ljust fält tvärs över hela fjädern. Det mörka på de inruggade pennorna är tydligt svartare jämfört med det brunaktiga hos de juvenila fjädrarna. Nya adulta pennor är också vanligen varmare gulbruna. 
most entirely dark feathers with narrow pale edge, but the difference in shape, quality, and colour is usually obvious (Figure 14). Note that young birds with a complete set of post-juvenile RR may be found from October onwards.

Adult females often give a greyer general impression of the wing than the dull brownish-grey colouration of juvenile wings. 1cy females rarely show distinctly contrasting grey outer vanes to primary coverts, which many adult females do. On the other hand, only young females occasionally have pale/whitish tips to outer vane. As in males, adult female PC are on average broader and rounder than juvenile PC. Adult primaries may also be broader and their better quality makes them less often appear heavily worn.

Patterns of female MC and LC appear more varying than in males, so age determination by this character is only possible in very few individuals. Most juveniles have a generally greyish-brown colouration (Figure 15), and some juvenile females show obviously narrow, pointed, and worn coverts not seen in adults. In contrast, some adult females show smoothly rounded MC and LC with a greyish cast that appears distinctive (Figure 16). However, on rare occasions, even young females have a greyer covert area. Both juveniles and adults may have MC and LC edged greyish-buff or warm buff (even white tips to longest $\mathrm{MC}$ as in Figure 16). The same is true for a male-like chestnut hue to $\mathrm{MC}$ and $\mathrm{LC}$, which are then more uniform and lack obvious edging. This is likely more common in adult females.

As in males, juvenile female greater coverts are generally narrower and more pointed (Figure 15) compared to adult GC (Figure 16), but the black terminal band is on average narrower in females than in males. Pattern differences between age classes are similar within the sexes. Consequently, adult females have broader and more even bands than juvenile females. The black is fading in the 3-6 outer GC in juveniles (Figure 15), whereas distinct black is usually present (on both vanes) out to GC3 in adult females (Figure 16). Buffish-white tips to (mainly outer) GC are more common in juveniles. Adult females generally show more distinct border between

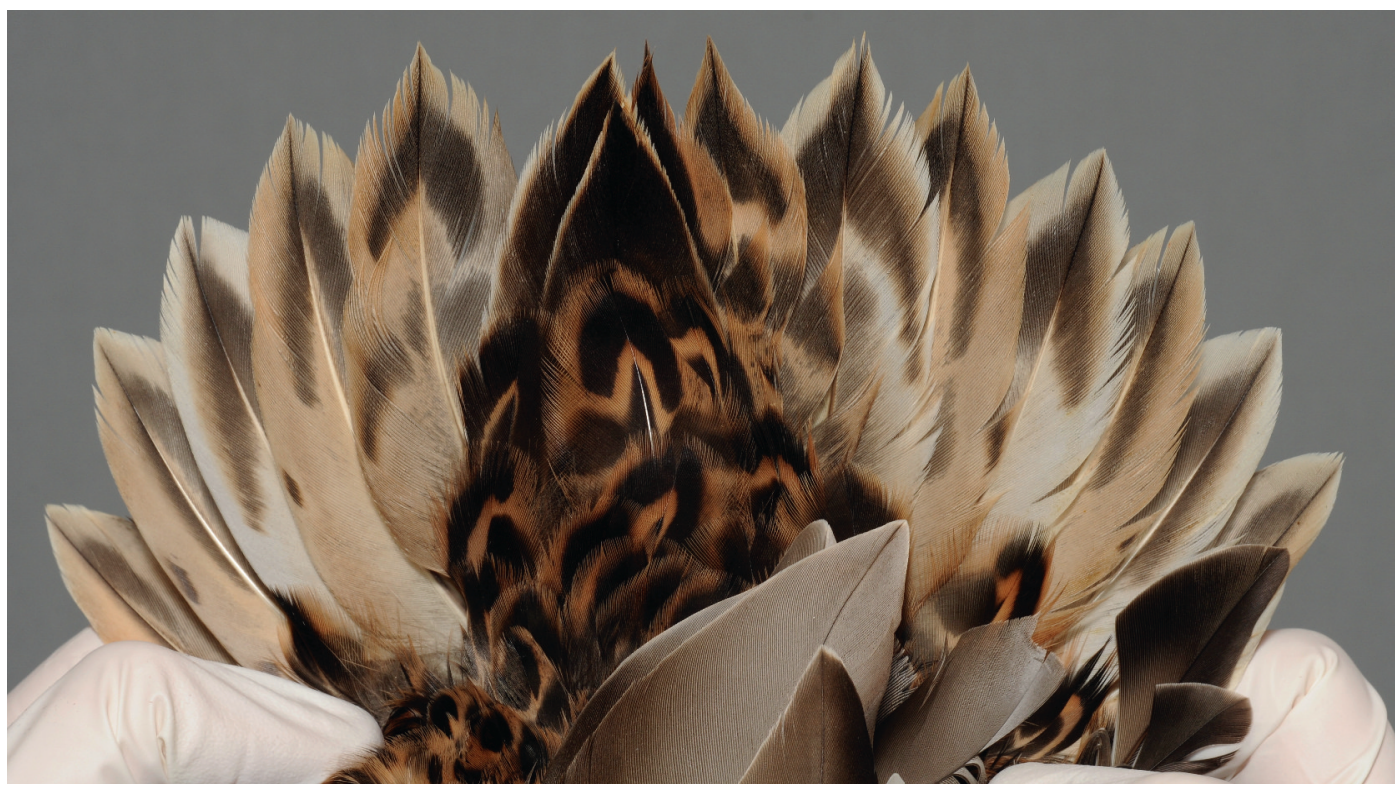

Figure 14. $2 c y+$ female, September. Sometimes two generations of feathers are present. Feathers from the older generation (R5, R7, R9-10 on the right-hand side) are bleached but still have typical adult shape and patterns, and they are not heavily worn. Note the extensive pale areas, some cutting through the feather almost horizontally, a pattern never observed in juveniles. Except for the dark end of the shaft, most rectrices are broadly tipped buff or buffish-white. Central RR are almost entirely blackish with only a narrow pale edge, a pattern more often present in juveniles, but seen in some adults too.

$2 c y+$ hona $i$ september. Ibland finns två generationer av adulta fjädrar samtidigt. Fjädrar från den äldre generationen (R5, R7, R9-10 på högra sidan) har blekts men har fortfarande typiskt adult utseende och de är inte kraftigt slitna. Observera de stora ljusa fälten, av vilka en del skär genom hela fjädern horisontellt, ett mönster som aldrig ses hos juveniler. Förutom de mörka spolspetsarna har de flesta pennorna breda gulbruna eller vitaktigt gulbruna spetsar. De centrala RR är nästan helt svarta med bara en smal blek kant, ett mönster som oftare ses hos juvenila men också hos vissa adulta. 
black and white on GC, whereas the border to grey is often diffuse in adult females too.

Juvenile female tertials are often frayed, faded (from blackish-brown when fresh), and narrower compared to post-juvenile TT, although differences are smaller than in males. The dark brown TT of juveniles often show distinct buffish-white tip and edges (Figure 17). Adult females generally have greyer TT with obvious grey colouration on T1 and $\mathrm{T} 2$, especially along the shaft, and warmer brown edges on the outer vanes. Some even mirror the TT pattern of males. On adult T3 and T4, the grey fades into blackish towards the body (same pattern, is often present on $\mathrm{T} 1$ and T2, but less obvious and generally hidden behind T3 and T4), although T4 is sometimes almost uniformly blackish-grey (Figure $18)$.

Tertial coverts of juvenile females are narrower than in adult females, also showing a higher degree of wear and duller dark brownish-grey colouration (Figure 17). Adult TC have either a greyer or warmer brown colouration. The tips of outer juvenile TC have buffish-white tips, but they do not generate a pure white continuum with the white GC wingbar present in adult females (Figure 18). Inner TC may have only a narrow buffish-white tip even in adult females. Also in females, juvenile TT and TC may be replaced as autumn proceeds. New feathers contrast in both shape and colour against retained juvenile feathers.

Female post-humerals show less obvious agedifferentiation compared to males, but differences still persist: typical juvenile $\mathrm{PH}$ are narrow and dark brownish-grey, whereas typical adult PH are greyer, broader, and rounder. Again, juvenile feathers are of poorer quality, so juvenile $\mathrm{PH}$ often show heavier signs of wear compared to adult $\mathrm{PH}$.

The longest two scapulars look similar to $\mathrm{PH}$, although the former are more pointed, and the differences between the two age classes follow the same pattern as in $\mathrm{PH}$. Feather patterns on the rest of the scapular area are more complex in adult fe-

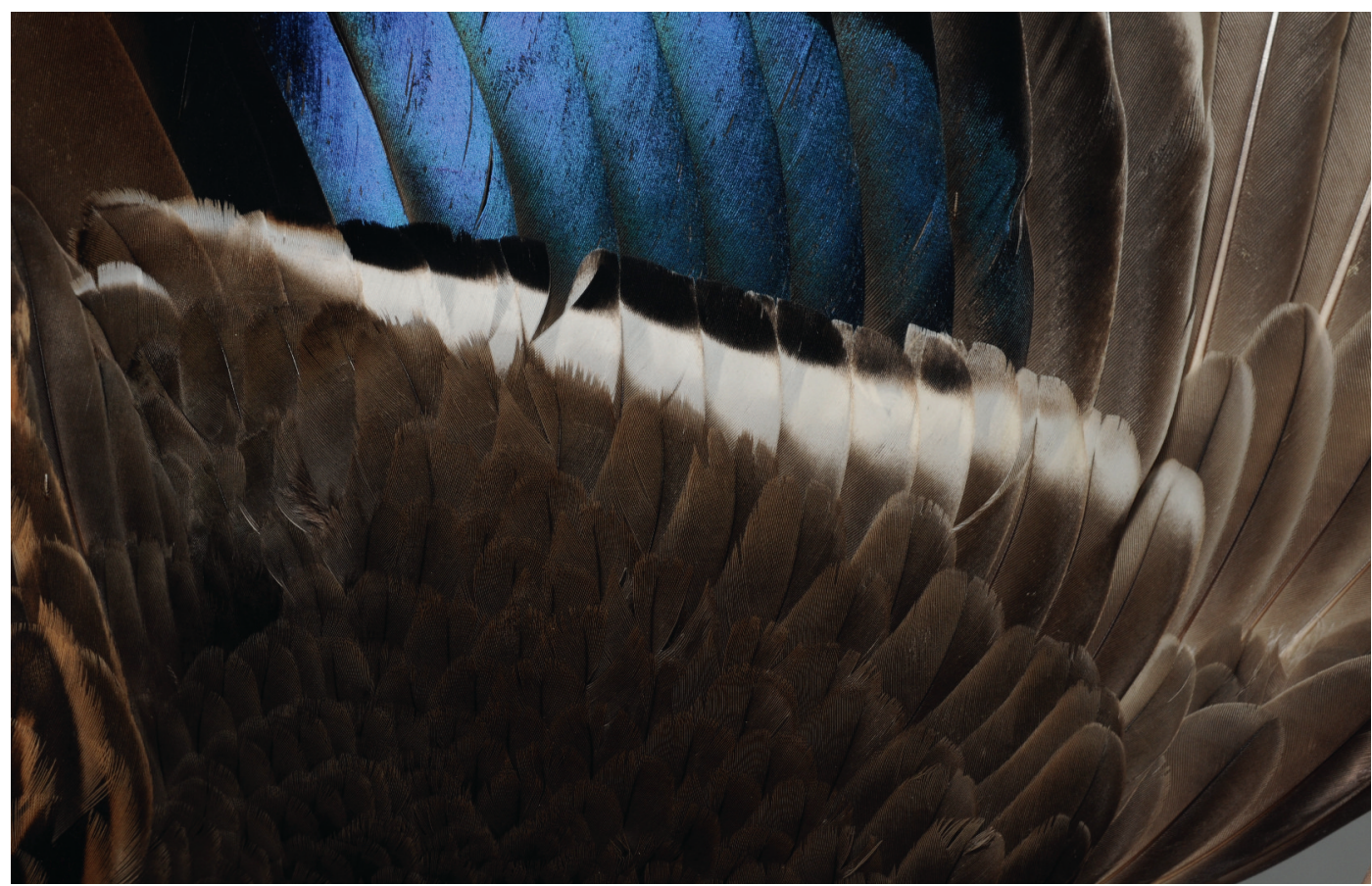

Figure 15. 1cy female, October. Juvenile LC and MC are generally greyish-brown. The narrower and slightly more pointed shape of juvenile coverts may be present in all coverts shown here, but is usually more obvious in GC. The black tips usually form a rather uneven band that is much reduced in the outer part of the arm, in this case no black in GC1-4 and diffuse black in GC5-6. Note growing inner TC with pure white tip.

1cy hona i oktober. Juvenila LC och MC är vanligen gråbruna. Det smalare och spetsigare utseendet hos juvenila täckare kan finnas hos alla täckare men är vanligen tydligast hos GC. De svarta spetsarna bildar vanligen ett ganska ojämnt band som är starkt reducerat $i$ yttre armen, $i$ detta fall saknas svart hos GC1-4 och är diffust hos GC5-6. Notera den växande inre TC med rent bit spets. 
males, having more internal markings (as in RR), and the pale colour is warmer buff. This is, however, a quite unreliable character due to the fact that scapulars are among the first to be moulted.

\section{Reliability test of age characters}

Tertials and rectrices show distinctive character differences between juvenile and adult males and females, respectively. Tertial coverts are usually also quite distinguishable, especially in females. These characters have been pointed out in previous publications dealing with ageing of ducks (Baker 1993, Boyd et al. 1975, Carney 1992, Carney \& Geis 1960, Mouronval 2014). However, in late autumn (mainly October-December), 1cy birds acquire new rectrices, tertials, tertial coverts, posthumerals, and scapulars, which are identical in appearance to adult feathers. Therefore, already from October some 1 cy birds may not be safely identified to age. The other described criteria are gen- erally more subtle and include subjective judgements, except for individuals showing extremely typical features. The last juvenile wing coverts and remiges are replaced during the second summer, i.e. when birds are approximately one year old, and may thus be used for ageing until then.

After TT, RR, and TC, the shape and patterns of $\mathrm{GC}$ seem to be the most useful character. In an attempt to propose statistically detectable features for ageing mallards, the black-and-white surface area of GC2 and GC3 was determined the single most reliable character for both males and females (Krapu et al. 1979). The detailed measurement method of that study (executed on feathers removed from birds) is, however, neither suitable nor possible to use on the individual level in field situations.

In the blind test we conducted on experienced ringers, no single character identified all mallards to age correctly (Table 5). For example, only $50 \%$ of the pictures of male and $57 \%$ of female MC and LC were correctly aged. The corresponding num-

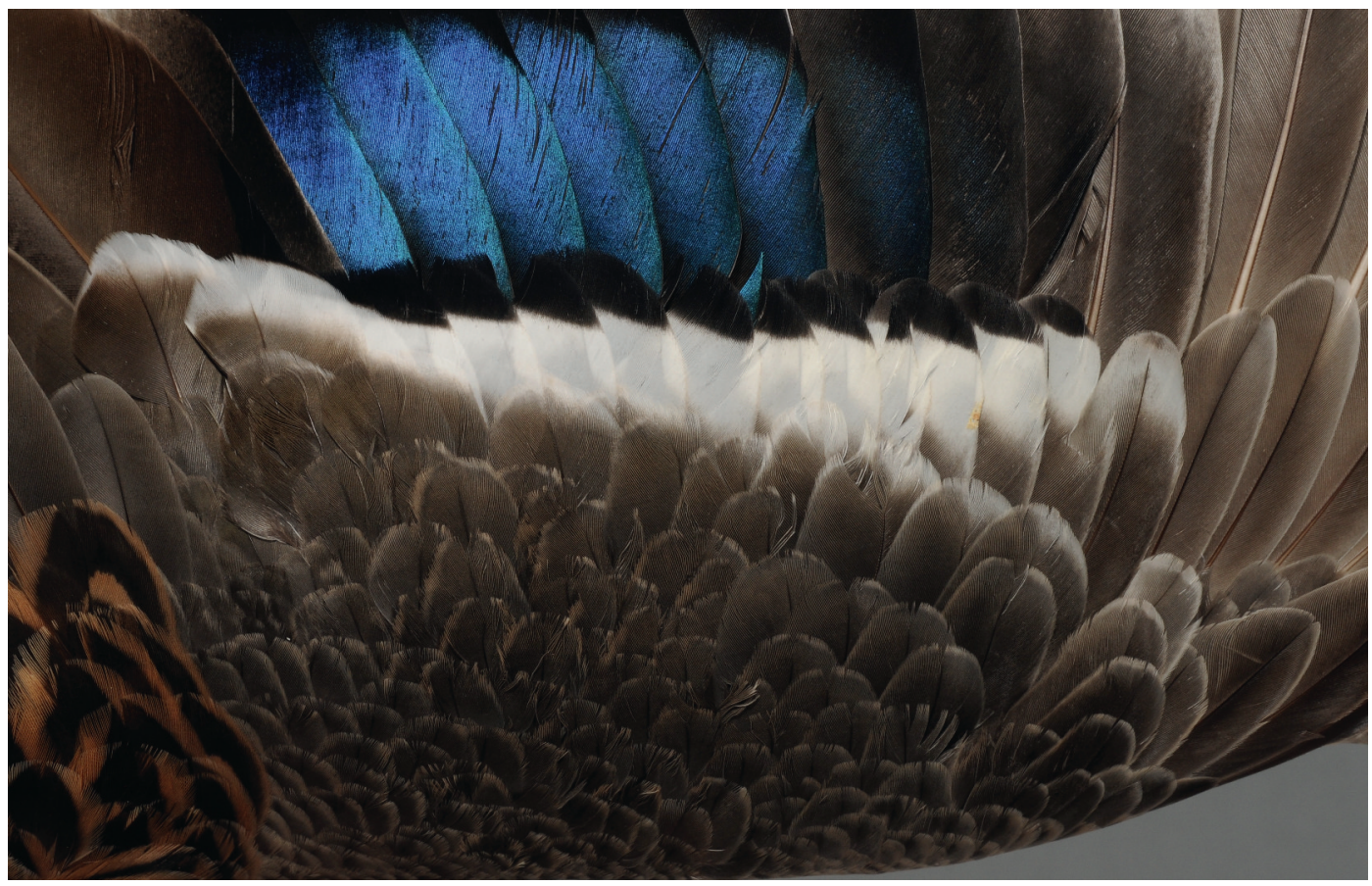

Figure 16. 2cy+ female, October. MC and LC are generally more greyish compared to juveniles. LC, MC and GC are slightly broader with a somewhat blunter tip. The black tips are usually reduced on the outer GC, but are generally present on both vanes to GC3 (GC2 in this individual). There is usually a sharper contrast between the black and white of each adult GC. Note also the broad and fresh TC with pure white tips.

$2 c y+$ hona $i$ oktober. MC och LC är $i$ allmänhet gråare än hos juvenila. LC, MC och GC är något bredare med trubbigare spetsar. De svarta spetsarna är vanligen reducerade på de yttre $G C$, men finns $i$ allmänhet på båda fanen hos GC3 (GC2 hos denna individ). Kontrasten mellan svart och vitt hos varje adult GC är vanligen skarpare. Observera också de breda och fräscha TC med rent vita spetsar. 
bers for $\mathrm{PH}$ was $51 \%$ and $48 \%$, respectively. As presumed, TT were most correctly identified: $85 \%$ of the male and $89 \%$ of the female pictures. Given that one 1cy male had acquired complete adult TT, the actual correct feather age was $94 \%$ in males. The frequency of correct answers was surprisingly low for male RR $(71 \%)$, but considering that one young bird was "misidentified" by all participants due to completed moult and the fact that two adult birds looked as if they had retained juvenile RR due to wear and dirt, the result was in the expected range. The individual performance by the participants varied between $59 \%$ and $81 \%$ for the single character test in males, and between 58\% and $87 \%$ in females. It deserves to be mentioned that judging age of mallards from a single picture does not mirror a real field situation, when examination includes the collective judgement of several (if not all) criteria at the same time.

In the second set-up, when all age characters were presented for 20 mallard individuals, the fre- quency of correct answers varied between $80 \%$ and $100 \%$ (average $91 \%$ ) in males. The corresponding figures in females were $85-100 \%$ (average $95 \%$ ). The misidentified individuals mainly referred to either 1cy birds that had replaced all of their RR and TT, or adults that, for one reason or another, had juvenile-like rectrices and tertials. The lower frequency of correct answers in males may be explained by a higher number of adult individuals represented among the pictures, namely 12 out of 20 in males compared to 6 out of 20 in females. (This may also include a confirmation bias, as the experienced ringers would expect a higher frequency of juvenile birds, given the situation in the field where juveniles are in excess.) As aforementioned, juveniles are more safely identified to age, since present juvenile feathers are usually easy to detect. In the field, difficult individuals are left unaged. Finally, it should be noted that ageing from pictures is likely to give more incorrect determinations than in a field situation due to e.g. lighting.

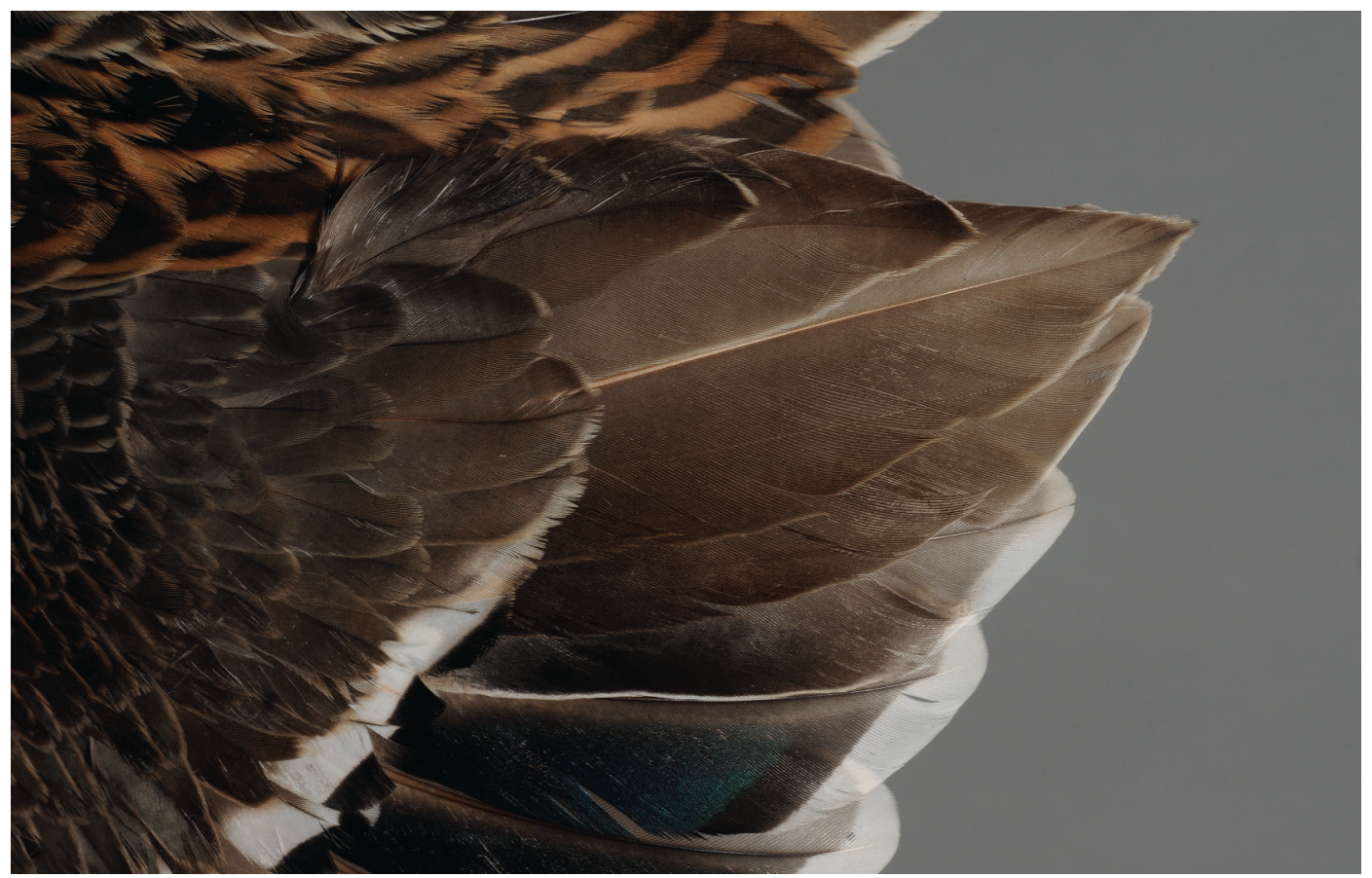

Figure 17. 1cy female, October. The juvenile tertials are quite narrow and show obvious signs of wear. The colour is mainly dark brown, often with distinct pale edges or tips (most obvious on the inner TT). The tertial coverts are also slightly narrower and more worn than those of adults. In this female, buffish-white fringes are present on all large tertial coverts, broadest on outer TC producing continuum with the greater coverts wingbar, although less conspicuous than in adult females.

1cy hona $i$ oktober. De juvenila tertialerna är smala och tydligt slitna. De är mörkt bruna med ljusa kanter och spets (tydligast hos de inre TT). Tertialtäckarna är också något smalare och mer slitna än hos adulta. Hos denna hona har alla större tertialtäckarna vitaktigt gulbruna kanter, bredast hos de yttre TC. De bildar en enhet med större vingtäckarnas vingband fast mindre tydligt än hos gamla honor. 


\section{Conclusions}

Based on our study, we conclude that differences in juvenile tertials and tail feathers are the most easily detectable age characters for both sexes of mallards. Other characters were subject to large variation, and should not be used other than as supportive criteria. Mallards with only post-juvenile TT and RR may preferably be left unaged, if not showing typical juvenile criteria in other features. Judging age of mallards by single characters is often impossible, especially from photos, and some individuals may even be challenging with all characters at hand.

\section{Supporting information}

The collective findings have been condensed into a short key and legends of 82 illustrative pictures of mallard characters in Ottenby Bird Observatory's online digital identification guide. This can be found at http://www.ringersdigiguide.ottenby. se/anas-platyrhynchos/OS.

\section{Acknowledgements}

We would like to thank all the Ottenby staff members who have been part of the duck trap project, especially those who battled the harsh and cold circumstances in late autumn (when duck numbers were often substantial). Our gratitude also embraces the ten Ottenby ringers participating in the age determination test. This is contribution no. 289 from Ottenby Bird Observatory.

\section{Sammanfattning}

Gräsanden Anas platyrhynchos är världens talrikaste simand. Dess utbredning täcker i princip hela norra halvklotet och den saknas egentligen bara allra längst i norr, i ökentrakter samt i tropikerna. Den europeiska populationen uppskattas till 7,5 miljoner individer (Wetlands International 2006, 2015), vartill skall adderas flera miljoner gräsänder som

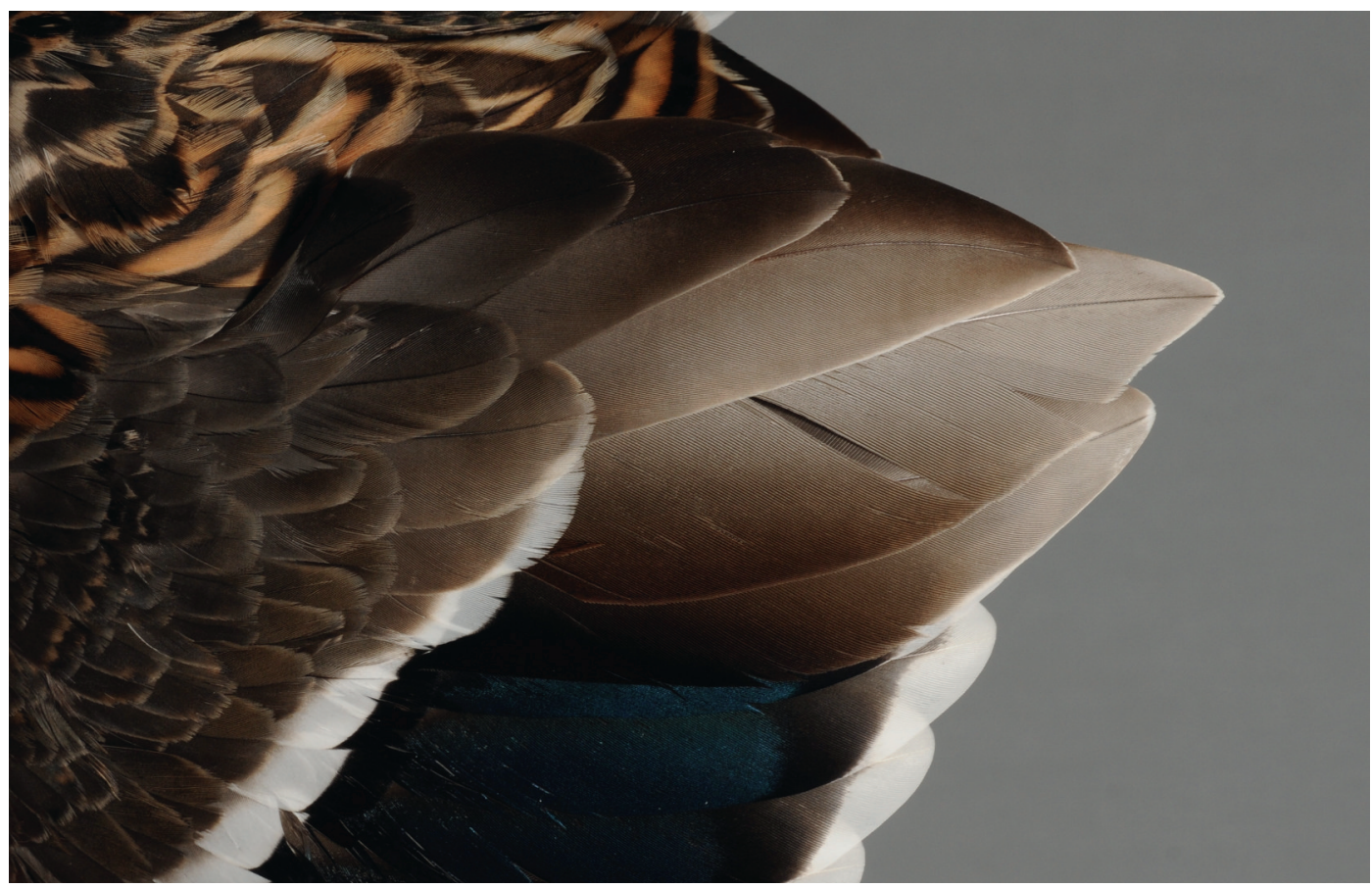

Figure 18. 2cy+ female, October. Some adult females develop silvery-grey, male-like, tertials, even with a tinge of chestnut on the outer web of T1 and T2. Note distinctly dark inner web of T3 and quite uniformly dark brownish-grey T4. The tips of the outer TC are distinctly and broadly tipped pure white. Also note two generations of adult feathers in the scapular area, older ones being bleached and thus paler.

$2 c y+$ hona i oktober. Vissa adulta honor utvecklar silvergrå, hanliknande tertialer, även med kastanjebrunt på yttre fanen av T1 och T2. Observera det tydligt mörka innerfanet hos T3 och den enfärgat brungrå T4. Spetsarna hos de yttre TC breda och rent vita. Notera också två generationer av adulta fjädrar bland skulderfjädrarna, där de äldre är blekta. 
Table 5. Percentage of correctly aged mallards when showing just one character for each individual $(\mathrm{n}=100$ males and 100 females). 1cy birds with completed moult (in RR, TT, TC or PH) were still considered juvenile and thus counted as incorrectly aged if judged to be adult (although the latter is actually correct according to feather generation).

Procent rätt åldersbestämda gräsänder vid användning av bara en egenskap för varje individ (100 hanar och 100 honor). Individer av ålder 1cy som ruggat RR, TT, TC eller PH betraktades fortfarande som ungfäglar och räknades in bland de felaktigt åldersbestämda om de bestämts till adulta (trots att det senare är rätt baserat på fjädergeneration). Svensk fjäderterminologi i Tabell 1.

\begin{tabular}{lcc}
\hline Character & \multicolumn{2}{c}{ \% correctly assigned } \\
Karaktär & \multicolumn{2}{c}{ \% rätt åldersbestämda } \\
\cline { 2 - 3 } & 71 & Male Hane \\
\hline Rectrices (RR) & 85 & 84 \\
Tertials (TT) & 73 & 79 \\
Tertial coverts (TC) & 76 & 85 \\
Greater coverts (GC) & 50 & 57 \\
Median and lesser coverts (MC \& LC) & 59 & 61 \\
Primary coverts and primaries (PC \& PP) & 51 & 48 \\
Post-humerals (PH) & 70 & 70 \\
Bill Näbb & 74 & 62 \\
Feet Fötter & 68 & 70 \\
\hline Total & & \\
\hline
\end{tabular}

sätts ut för jakt varje år (Champagnon et al. 2013). Gräsanden är föremål för omfattande studier inom bl.a. ekologi (Gunnarsson et al. 2006), jakt (Nichols et al. 2007) och epidemiologi (Wallensten et al. 2007). I alla dessa avseenden är åldersbestämning mycket betydelsefull för korrekta analyser. Kännedom om ändernas ruggningscykel är avgörande för att kunna åldersbestämma gräsänder.

Med utgångspunkt från 119 fotodokumenterade gräsänder med känd ålder (ringmärkta som 1 cy vid Ottenby fågelstation) beskriver vi i denna artikel nio användbara dräktkaraktärer för åldersbestämning av gräsänder på hösten. För att kvantifiera pålitligheten hos respektive karaktär genomfördes ett test där tio representanter ur fågelstationens ringmärkningspersonal fick bedöma ålder på fotograferade fåglar. I en första studie fick deltagarna se tio bilder på var och en av de nio karaktärerna och bedöma huruvida den fotograferade individen var ung eller gammal (totalt 90 bilder på hanar och 90 bilder på honor). I nästa studie skulle tjugo gräsandsindivider av varje kön åldersbestämmas med tillgång till bilder på alla nio karaktärerna.

Resultaten av den första studien visade att när bara en enstaka dräktdetalj kunde studeras blev osäkerheten i åldersbestämningen stor och bara $51-85 \%$ av hanarna respektive $48-89 \%$ av honorna placerades i rätt ålderskategori. (Notera att 1cyfåglar som ruggat till postjuvenil dräkt bedömdes som felaktigt åldersbestämda utifall de bestämdes till adulta, även om beslutet alltså egentligen var korrekt med avseende på fjädarnas utseende.)

För både hanar och honor var utfallet sämst för posthumeraler, där man i genomsnitt alltså bara bedömde ungefär hälften av bilderna rätt, medan bilderna på tertialer renderade flest korrekta svar (85\% respektive $89 \%$ ). I den andra studien där alla nio karaktärerna kunde studeras samtidigt blev 91\% av hanarna och $95 \%$ av honorna placerade i rätt åldersgrupp.

Så länge det finns kvarvarande juvenila tertialer eller stjärtpennor är sådana relativt lätta att identifiera och många gräsänder, såväl hanar som honor, kan därmed åldersbestämmas korrekt på hösten. Inom övriga karaktärer förekommer så stor variation att endast mycket typiska individer kan bestämmas med säkerhet. Allteftersom ruggningen fortskrider får även ungfåglar (från oktober och framåt) tertialer och stjärtpennor av samma utseende som äldre gräsänder. Detta komplicerar åldersbestämningsmöjligheterna och individer som ruggat färdigt dessa fjädergrupper bör lämnas obestämda till ålder om det inte föreligger övertygande bevis inom andra karaktärer.

En bestämningsnyckel och ett större bildmaterial av gräsänder finns tillgängligt i Ottenby fågelstations digitala guide för ålders- och könsbestämning av fåglar i handen på webbadressen http://www. ringersdigiguide.ottenby.se/anas-platyrhynchos/OS. 


\section{References}

Ashley, E.P., Petrie, S.A., North, N.R. \& Bailey, R.C. 2007. Tertial and upper wing covert molt in young American Black Ducks. Waterbirds 30(3): 433-440.

Baker, K. 1993. Identification guide to European non-passerines. British Trust for Ornithology. 332 pp.

Beauchamp, G. 2004. Reduced flocking by birds on islands with relaxed predation. Proceedings of the Royal Society B-Biological Sciences 271(1543): 1039-1042.

Boyd, H., Harrison, J. \& Allison, A. 1975. Duck wings: a study of duck production. WAGBI conservation publication, Marley Ltd. and the Harrison Zoological Museum, Chester, Great Britain. 112 pp.

Carney, S.M. 1992. Species, age and sex identification of ducks using wing plumage. U.S. Department of the Interior, U.S. Fish and Wildlife Service, Washington, D.C. $144 p p$.

Carney, S.M. \& Geis, A.D. 1960. Mallard age and sex determination from wings. The Journal of Wildlife Management 24(4): 372-381.

Champagnon, J., Crochet, P.A., Kreisinger, J., Cizkova, D., Gauthier-Clerc, M., Massez, G., Söderquist, P., Albrecht, T. \& Guillemain, M. 2013. Assessing the genetic impact of massive restocking on wild mallard. Animal Conservation 16(3): 295-305.

Costa, T.P., Brown, J.D., Howerth, E.W. \& Stallknecht, D.E. 2010. The effect of age on avian influenza viral shedding in Mallards (Anas platyrhynchos). Avian Diseases 54(s1): 581-585.

Cramp, S. \& Simmons, K.E.L. 1977. Birds of the Western Palearctic, vol 1. Oxford University Press, Oxford. 722 pp.

Ginn, H.B. \& Melville, D.S. 1983. Moult in birds. British Trust for Ornithology. $112 \mathrm{pp}$.

Gunnarsson, G., Elmberg, J., Sjöberg, K., Pöysä, H., \& Nummi, P. 2006. Experimental evidence for density-dependent survival in mallard (Anas platyrhynchos) ducklings. Oecologia 149(2): 203-213.
Hauser, C.E., Runge, M.C., Cooch, E.G., Johnson, F.A. \& Harvey, W.F. 2007. Optimal control of Atlantic population Canada geese. Ecological Modelling 201(1): 27-36.

Hochbaum, H.A. 1942. Sex and age determination of waterfowl by cloacal examination. Transactions of the North American Wildlife and Natural Resources Conference 7: 299-307.

Hopper, R.M. \& Funk, H.D. 1970. Reliability of Mallard wing age-determination technique for field use. Journal of Wildlife Management 34(2): 333-339.

Krapu, G.L., Johnson, D.H. \& Dane, C.W. 1979. Age-determination of Mallards. Journal of Wildlife Management 43(2): 384-393.

Mouronval, J.B. 2014. Guide de détermination de l'âge et du sexe des canards. Office national de la chasse et de la faune sauvage, Paris. $124 \mathrm{pp}$.

Nichols, J.D., Runge, M.C., Johnson, F.A. \& Williams, B.K. 2007. Adaptive harvest management of North American waterfowl populations: a brief history and future prospects. Journal of Ornithology 148: S343-S349.

Reeber, S. 2015. Wildfowl of Europe, Asia and North America. Christopher Helm, London. 655 pp.

Wallensten, A., Munster, V.J., Latorre-Margalef, N., Brytting, M., Elmberg, J., Fouchier, R.A.M., Fransson, T., Haemig, P.D., Karlsson, M., Lundkvist, Å., Osterhaus, A.D.M.E., Stervander, M., Waldenström, J. \& Olsen, B. 2007. Surveillance of influenza A virus in migratory waterfowl in northern Europe. Emerging Infectious Diseases 13(3): 404-411.

van Dijk, J.G.B., Hoye, B.J., Verhagen, J.H., Nolet, B.A., Fouchier, R.A.M. \& Klaassen, M. 2014. Juveniles and migrants as drivers for seasonal epizootics of avian influenza virus. Journal of Animal Ecology 83(1): 266-275.

Wetlands International. 2006. Waterbird population estimates, fourth edition. Wetlands International, Wageningen, The Netherlands. 239 pp.

Wetlands International. 2015. Waterbird population estimates. http://wpe.wetlands.org/. 